\title{
Effect of different emission inventories on modeled ozone and carbon monoxide in Southeast Asia
}

\author{
T. Amnuaylojaroen ${ }^{1,2}$, M. C. Barth ${ }^{2}$, L. K. Emmons ${ }^{2}$, G. R. Carmichael $^{3}$, J. Kreasuwun ${ }^{1,4}$, S. Prasitwattanaseree ${ }^{5}$, \\ and S. Chantara ${ }^{1}$ \\ ${ }^{1}$ Environmental Science Program and the Center for Environmental Health, Toxicology and \\ Management of Chemical, Chiang Mai University, Faculty of Science, Chiang Mai, Thailand \\ ${ }^{2}$ Atmospheric Chemistry Division (ACD), National Center for Atmospheric Research (NCAR), \\ Boulder, CO, USA \\ ${ }^{3}$ Center for Global and Regional Environmental Research, The University of Iowa, Iowa City, IA, USA \\ ${ }^{4}$ Department of Physics and Materials Science, Faculty of Science, Chiang Mai University, Chiang Mai, \\ Thailand \\ ${ }^{5}$ Department of Statistics, Faculty of Science, Chiang Mai University, Chiang Mai, Thailand
}

Correspondence to: T. Amnuaylojaroen (tum@ucar.edu) and M. C. Barth (barthm@ucar.edu)

Received: 5 March 2014 - Published in Atmos. Chem. Phys. Discuss.: 7 April 2014

Revised: 17 September 2014 - Accepted: 8 October 2014 - Published: 8 December 2014

\begin{abstract}
In order to improve our understanding of air quality in Southeast Asia, the anthropogenic emissions inventory must be well represented. In this work, we apply different anthropogenic emission inventories in the Weather Research and Forecasting Model with Chemistry (WRF-Chem) version 3.3 using Model for Ozone and Related Chemical Tracers (MOZART) gas-phase chemistry and Global Ozone Chemistry Aerosol Radiation and Transport (GOCART) aerosols to examine the differences in predicted carbon monoxide $(\mathrm{CO})$ and ozone $\left(\mathrm{O}_{3}\right)$ surface mixing ratios for Southeast Asia in March and December 2008. The anthropogenic emission inventories include the Reanalysis of the TROpospheric chemical composition (RETRO), the Intercontinental Chemical Transport Experiment-Phase B (INTEX-B), the MACCity emissions (adapted from the Monitoring Atmospheric Composition and Climate and megacity Zoom for the Environment projects), the Southeast Asia Composition, Cloud, Climate Coupling Regional Study (SEAC4RS) emissions, and a combination of MACCity and SEAC4RS emissions. Biomass-burning emissions are from the Fire Inventory from the National Center for Atmospheric Research (NCAR) (FINNv1) model. WRF-Chem reasonably predicts the $2 \mathrm{~m}$ temperature, $10 \mathrm{~m}$ wind, and precipitation. In general, surface $\mathrm{CO}$ is underpredicted by WRF-Chem while surface $\mathrm{O}_{3}$ is overpredicted. The $\mathrm{NO}_{2}$ tropospheric column
\end{abstract}

predicted by WRF-Chem has the same magnitude as observations, but tends to underpredict the $\mathrm{NO}_{2}$ column over the equatorial ocean and near Indonesia. Simulations using different anthropogenic emissions produce only a slight variability of $\mathrm{O}_{3}$ and $\mathrm{CO}$ mixing ratios, while biomass-burning emissions add more variability. The different anthropogenic emissions differ by up to $30 \%$ in $\mathrm{CO}$ emissions, but $\mathrm{O}_{3}$ and $\mathrm{CO}$ mixing ratios averaged over the land areas of the model domain differ by $\sim 4.5 \%$ and $\sim 8 \%$, respectively, among the simulations. Biomass-burning emissions create a substantial increase for both $\mathrm{O}_{3}$ and $\mathrm{CO}$ by $\sim 29 \%$ and $\sim 16 \%$, respectively, when comparing the March biomass-burning period to the December period with low biomass-burning emissions. The simulations show that none of the anthropogenic emission inventories are better than the others for predicting $\mathrm{O}_{3}$ surface mixing ratios. However, the simulations with different anthropogenic emission inventories do differ in their predictions of $\mathrm{CO}$ surface mixing ratios producing variations of $\sim 30 \%$ for March and 10-20\% for December at Thai surface monitoring sites. 


\section{Introduction}

Southeast Asia, which includes the Indochina peninsula and the Indonesian archipelago, can have significant air quality problems. Understanding the contribution of different sources of tropospheric ozone $\left(\mathrm{O}_{3}\right)$ and its precursors, carbon monoxide $(\mathrm{CO})$ and nitrogen oxides $\left(\mathrm{NO}_{\mathrm{x}}=\mathrm{NO}+\mathrm{NO}_{2}\right)$, for Southeast Asia provides valuable information on maintaining good air quality for both human well being and ecosystems. Previous studies examining air pollutants and their sources via regional model simulations have focused primarily on China (e.g., Wang et al., 2005; Geng et al., 2011), eastern Asia (Han et al., 2008; Tanimoto et al., 2009), and India (Adhikary et al., 2007; Kumar et al., 2012; Ghude et al., 2013). Here, we examine the effect of different emission inventories on modeled surface $\mathrm{O}_{3}$ and $\mathrm{CO}$ for Southeast Asia, a region generally ignored in previous studies.

Previous studies have indicated that both local anthropogenic and biomass-burning emissions, as well as emissions upstream are important for local $\mathrm{O}_{3}$ air quality in Asia. In eastern Asia, Tanimoto et al. (2009) noted relatively small changes in decadal $\mathrm{O}_{3}$ trends at sites near the Japanese coast, but a larger increase in measured $\mathrm{O}_{3}$ at a remote mountainous site in Japan. Using a regional chemistry transport model, Tanimoto et al. (2009) attributed half of the observed increase at the mountainous site to increasing anthropogenic emissions in Asia. The results from this study suggested that the actual growth in emissions between 1998 and 2007 was significantly underestimated. Using a nested eastern Asia domain within a global chemistry transport model, Wang et al. (2011) found that local sources of $\mathrm{O}_{3}$ precursors produced much of the $\mathrm{O}_{3}$ in the region; however, $\mathrm{O}_{3}$ transported from Europe, North America, India, and Southeast Asia also impacted $\mathrm{O}_{3}$ concentrations in eastern China depending on the season. Liu et al. (2008), using a regional air quality model, determined that fossil fuel and biomass-burning emissions from eastern Asia increased surface $\mathrm{CO}$ and $\mathrm{O}_{3}$ in Taiwan by $70-150 \%$ and $50-100 \%$, respectively, compared to model results that excluded background emissions. They attributed up to $20 \%$ of the surface $\mathrm{CO}$ and $\mathrm{O}_{3}$ in Taiwan to biomassburning emissions from eastern China. Both the aerosol optical depth and $\mathrm{O}_{3}$ concentrations in the Pearl River delta were also found to be affected by biomass-burning emissions occurring upstream in Southeast Asia (Deng et al., 2008).

Southeast Asia is subject to the outflow of pollution from the main continent, yet the region itself is rapidly growing and has increasing anthropogenic and biomass-burning emissions, which are especially high during the dry season (November-April). To simulate $\mathrm{O}_{3}$ production and concentrations in Southeast Asia, realistic estimates of emissions from both local and regional sources, including fossil fuel use, other anthropogenic activities, and biomass burning, must be available. Emission inventories for Asia have been developed by several groups (e.g., Akimoto and Narita, 1994; Streets et al., 2003; Ohara et al., 2007; Zhang et al., 2009; Kurokawa et al., 2013) for both chemistryclimate and air quality studies. For example, the REanalysis of the TROpospheric chemical composition (RETRO) and the Emission Database for Global Atmospheric Research (EDGAR) emissions inventories (Olivier et al., 2005; Schultz et al., 2007) are global emissions inventories developed for chemistry-climate studies. Streets et al. (2003) developed a 2001 emission inventory for the ACE-Asia (Asian Pacific Regional Aerosol Characterization Experiment) and TRACE$\mathrm{P}$ (Transport and Chemical Evolution over the Pacific) field campaigns which took place in the eastern Asian and western Pacific region during spring 2001. Zhang et al. (2009) developed a 2006 emissions inventory for Asia to support the Intercontinental Chemical Transport Experiment-Phase B (INTEX-B) field campaign. The INTEX-B field campaign emphasized China emissions because they dominate the Asia pollutant outflow to the Pacific. Ohara et al. (2007) developed the Regional Emission inventory in Asia (REAS) for 1980-2020 in order to conduct air quality studies for recent past, present-day, and near-future time periods. More recently, Kurokawa et al. (2013) released REAS version 2.1, providing updated emissions for each year from 2000 to 2008 for Asian countries east of $\sim 55^{\circ} \mathrm{E}$. The MACCity (adapted from the Monitoring Atmospheric Composition and Climate and megacity Zoom for the Environment projects) emissions inventory (Granier et al., 2011), which is an outcome from two European Commission projects (MACC and CityZen), is a 1980-2010 global emissions inventory for chemistry-climate studies. Most recently the Southeast Asia Composition, Cloud, Climate Coupling by Regional Study (SEAC4RS) emissions inventory (Lu and Streets, 2012) for 2012 emissions has been released for field campaign support. Four emission inventories, RETRO, INTEX-B, MACCity, and SEAC4RS, will be described in more detail in Sect. 3.

While previous studies (e.g., Ohara et al., 2007) have compared different emission inventories, a comparison of simulated surface $\mathrm{CO}$ and $\mathrm{O}_{3}$ mixing ratios resulting from different emission inventories, yet using the same model framework, has not been done. Here, the Weather and Forecasting Model coupled with Chemistry (WRF-Chem) is used to examine the variability of predicted $\mathrm{O}_{3}$ and $\mathrm{CO}$ surface mixing ratios when five different anthropogenic emission inventories (RETRO, INTEX-B, MACCity, SEAC4RS and a modified SEAC4RS) are used as inputs. By conducting this comparison using the same model, differences in results due to model meteorology are mitigated. We focus this study on Southeast Asia, an area that has received little attention, yet has substantial anthropogenic and biomass-burning emissions. As part of our study, we examine the effect of biomass-burning emissions on surface $\mathrm{O}_{3}$ and $\mathrm{CO}$ by the contrasting results from a low biomass-burning period (December) with a high biomass-burning period (March).

We begin this paper by describing the model configuration (Sect. 2) and emission inventories (Sect. 3) applied in the model simulations. We then evaluate the model results 
(Sect. 4) with available data sets. In Sect. 5, we compare the surface $\mathrm{O}_{3}$ and $\mathrm{CO}$ predictions among the different simulations in order to quantify the variability produced by the different emission inventories.

\section{Model description and configuration}

We use the Weather Research Forecasting Model (Skamarock et al., 2008) coupled with Chemistry (WRF-Chem version 3.3) to investigate the variation of $\mathrm{O}_{3}$ and $\mathrm{CO}$ predictions among different anthropogenic emissions inventories for Southeast Asia. The WRF-Chem model is a newgeneration regional air quality model (Grell et al., 2005; Fast et al., 2006) that shares the meteorology and chemistry routines, the same land surface schemes, time-transport schemes, vertical mixing parameterizations, and time steps for transport and vertical mixing.

For this study, one model domain was configured to cover the entire area of Southeast Asia and a part of China and India (Fig. 1). The model was run with a horizontal grid spacing of $36 \mathrm{~km}$ and 51 vertical levels from the surface to $10 \mathrm{hPa}$. The vertical grid spacing stretched from $\sim 60 \mathrm{~m}$ near the surface to $\sim 700 \mathrm{~m}$ near the tropopause. The initial and boundary conditions were from National Centers for Environmental Prediction (NCEP) final analysis (FNL) $1^{\circ} \times 1^{\circ}$ data for meteorological variables, which include winds, potential temperature, pressure, and water vapor. These variables and condensed water (i.e., cloud particles) and chemistry species were integrated forward in time using a Runge-Kutta integration method. The moisture variables and chemistry species were advected using a monotonic scheme (Wang et al., 2009). Grid nudging (Stauffer and Seaman, 1990) was employed for the horizontal wind, temperature, and water vapor for all vertical levels to ensure the accuracy of the large-scale meteorology during the month of simulation. The nudging coefficients for all variables were set to be $0.0003 \mathrm{~s}^{-1}$, and nudging was performed every 6 hours, consistent with the timing of the FNL data.

The model setup used the following modules and parameterizations. Cloud physics was represented by the Thompson et al. (2004) parameterization, which predicts the mass mixing ratio for rain, snow, and graupel and mass and number of cloud water and cloud ice. The Grell-3 scheme, based on the Grell and Devenyi (2002) scheme, was used for the parameterization of sub-grid convection. The planetary boundary layer was parameterized with the Mellor-Yamada-Janjic (MYJ) scheme (Janjic, 2002), and the Noah land surface model (Chen and Dudhia, 2001) was used to provide heat and moisture fluxes over land. For heating rates, the Goddard scheme (Chou and Suarez, 1994) was used for shortwave radiation and the Rapid Radiative Transfer Model (Mlawer et al., 1997) was used for long-wave radiation. Feedbacks between aerosols and the radiation scheme were not included in any simulations.
The model is integrated for a $61 / 2$ week period. The first 2 weeks are for spinning up the model from the initial conditions to a state that is primarily affected by the emissions. Initial and boundary conditions for the chemical species were provided by the global chemistry Model for Ozone and Related Chemical Tracers, version 4 (MOZART4; Emmons et al., 2010) 6-hourly output. MOZART4 includes 84 gas-phase species, 12 bulk aerosol compounds, 39 photolysis, and 127 gas-phase reactions. In our WRF-Chem simulations, gasphase chemistry was represented by the MOZART chemistry mechanism and aerosols by the GOCART representation (Chin et al., 2000). A kinetic pre-processor and Rosenbrock solver (Sandu et al., 2006) were applied. The photolysis rates were computed using fast-TUV ( tropospheric ultravioletvisible) (Tie et al., 2003), which modifies the photolysis rates based on the presence of aerosols and clouds in each model grid cell. Dry deposition of gases and aerosols followed the Wesely (1989) resistance method. Wet deposition of soluble gases was calculated using the method described by Neu and Prather (2012).

Emissions from biomass burning, undisturbed vegetation, and anthropogenic sources were included in the simulations. The Fire Inventory from the National Center for Atmospheric Research (NCAR) (FINN) model (Wiedinmyer et al., 2010) provided daily, $1 \mathrm{~km}$ resolution, global estimates of trace gas and particulate emissions from open burning including wildfires, agricultural fires, and prescribed burning for all the simulations conducted. Biofuel use and trash burning were not included in the FINN emission estimates. Biogenic emissions were computed online by the Model of Emissions of Gases and Aerosols from Nature (MEGAN) version 2.04 (Guenther et al., 2006), which uses WRF-predicted temperature and downward radiation for its calculations. The anthropogenic emission inventories used as inputs to the WRFChem simulations are described in Sect. 3.1.

\section{Emissions}

In this study we perform WRF-Chem simulations with four different anthropogenic emission inventories, consisting of RETRO, INTEX-B, MACCity, and SEAC4RS, and an inventory combining MACCity and SEAC4RS emissions. The simulations also include biogenic emissions (MEGAN v2.04) and biomass burning (FINNv1) emissions, which were the same in all simulations. Different groups have compiled the different anthropogenic emission inventories for different years: RETRO for 2000, INTEX-B for 2006, MACCity for 2010, and SEAC4RS for 2012. The emission inventories have in common several sectors contributing to the emissions (Table 1), but there are some sectors not included in one or two inventories that are detailed below. Due to these differences, the total emissions and associated uncertainties for the region are variable. The five emission inventories were applied to (1) evaluate surface $\mathrm{CO}$ and $\mathrm{O}_{3}$ predic- 


\section{E_CO, (mole/km2/hr)}
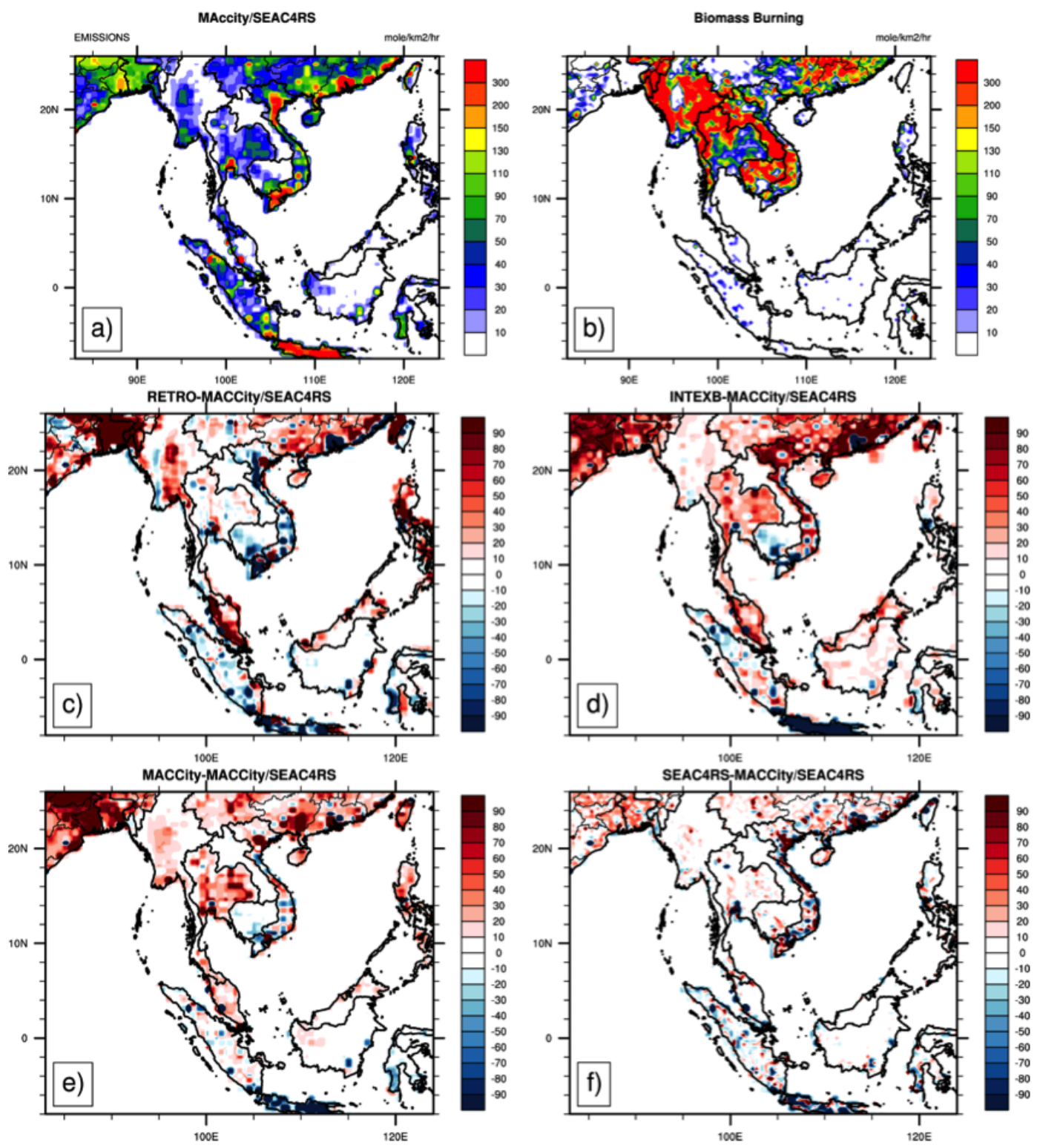

Figure 1. CO emissions for March 2008 from different emission inventories: (a) MACCity-SEAC4RS, (b) biomass burning, (c) RETRO - MACCity-SEAC4RS, (d) INTEX-B - MACCity-SEAC4RS, (e) MACCity - MACCity-SEAC4RS, and (f) SEAC4RS - MACCitySEAC4RS.

tions with monitoring station observations and (2) determine the extent to which the model predictions are limited by variations in the emissions inventories.

\subsection{Description of the anthropogenic emission inventories}

The RETRO project aimed at analyzing the long-term changes in the atmospheric budget of trace gases and aerosols over the time period from 1960 to 2000. The RETRO anthropogenic emissions (Schultz et al., 2007) are derived from a preliminary version of the TNO (Netherlands Organization for Applied Scientific Research) emissions, for the 19602000 time period with spatial resolution of $0.5^{\circ} \times 0.5^{\circ}$. The anthropogenic emissions in the RETRO inventory include mainly combustion sources (Granier et al., 2011), but solvent use and other industrial processes are included (Table 1). Schultz et al. (2007) report several uncertainties associated with the RETRO emissions. These uncertainties include omission of specific sectors (e.g., railway traffic or cement manufacturing), underestimation of $\mathrm{CO}$ combustion emissions and $\mathrm{NO}_{\mathrm{x}}$ ship traffic emissions, and the lack of 


\section{E_CO, (mole/km2/hr)}


Figure 2. CO emissions for December 2008 from different emission inventories: (a) MACCity-SEAC4RS, (b) biomass burning, (c) RETRO - MACCity-SEAC4RS, (d) INTEX-B - MACCity-SEAC4RS, (e) MACCity - MACCity-SEAC4RS, and (f) SEAC4RS - MACCitySEAC4RS.

weekly and diurnal profiles of emissions. For the Southeast Asia region the RETRO seasonal cycle is based on the Long Term Ozone Simulation and European Operational Smog (LOTOS-EUROS) European monthly pattern (Schaap et al., 2005; which is derived from a critical review of the monthly variation by emission sector), but has a reduced amplitude. Kurokawa et al. (2013) show that there is very little seasonal cycle for anthropogenic emissions of $\mathrm{NO}_{\mathrm{x}}$ and black carbon over India, which is a region similar to Southeast Asia in terms of climate. The RETRO inventory provided regional information for the emissions of a variety of non- methane volatile organic compounds (NMVOCs) including ethane, propane, butanes, pentanes, hexanes and higher alkanes, ethene, propene, ethyne, other alkenes and alkynes, benzene, toluene, xylene, trimethyl benzenes and other aromatics, organic alcohols, esters, ethers, chlorinated hydrocarbons, formaldehyde and other aldehydes, ketones, organic acids, and other VOCs.

As part of the INTEX-B field campaign, which was conducted by the National Aeronautics and Space Administration (NASA) in spring 2006, anthropogenic emissions were developed for the specific year and season as the field cam- 


\section{E_NO, (mole/km2/hr)}
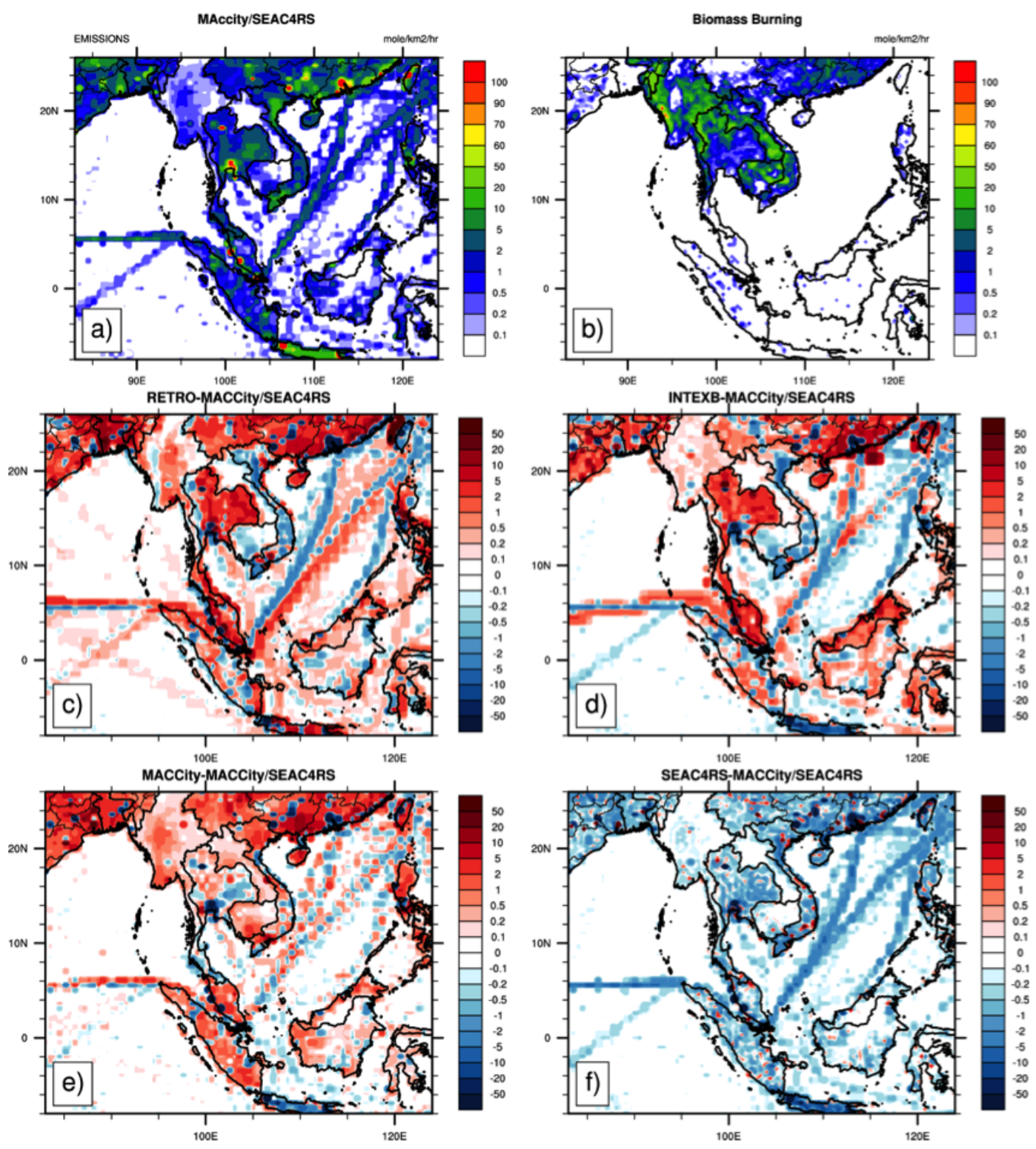

Figure 3. Nitrogen oxides emissions for March 2008 from different emission inventories: (a) MACCity-SEAC4RS, (b) biomass burning, (c) RETRO - MACCity-SEAC4RS, (d) INTEX-B - MACCity-SEAC4RS, (e) MACCity - MACCity-SEAC4RS, and (f) SEAC4RS - MACCitySEAC4RS.

paign (Zhang et al., 2009). The emissions are estimated for eight major chemical species, sulfur dioxide $\left(\mathrm{SO}_{2}\right), \mathrm{NO}_{\mathrm{x}}$, $\mathrm{CO}$, NMVOCs, $\mathrm{PM}_{10}, \mathrm{PM}_{2.5}$, black carbon (BC) and organic carbon $(\mathrm{OC})$, with a spatial resolution of $0.5^{\circ} \times 0.5^{\circ}$. To represent the individual VOCs represented in the MOZART mechanism, the NMVOC emissions are speciated based on the ratios of the individual VOC to the total NMVOCs derived from the RETRO inventory; that is, the individual VOC fraction from the RETRO inventory is multiplied with the total INTEX-B NMVOC to get the individual VOC emissions. The INTEX-B emissions contain four major sectors
(Table 1): power generation, industry, residential, and transportation. The uncertainty of the INTEX-B emissions for the Southeast Asian countries is estimated to be similar to the TRACE-P emissions uncertainty (Zhang et al., 2009), e.g., $\pm 37 \%$ for $\mathrm{NO}_{\mathrm{x}}$ emissions and $\pm 185 \%$ for $\mathrm{CO}$ emissions. The INTEX-B emissions uncertainties for China are smaller $\left( \pm 31 \%\right.$ for $\mathrm{NO}_{\mathrm{x}}$ and $\pm 70 \%$ for $\left.\mathrm{CO}\right)$.

The MACCity emissions (Granier et al., 2011) are an outcome of two European Commission projects, MACC (Hollingsworth et al., 2008) and CityZen (http: //cityzen-project.eu) and are an extension of the the At- 


\section{E_NO, (mole/km2/hr)}
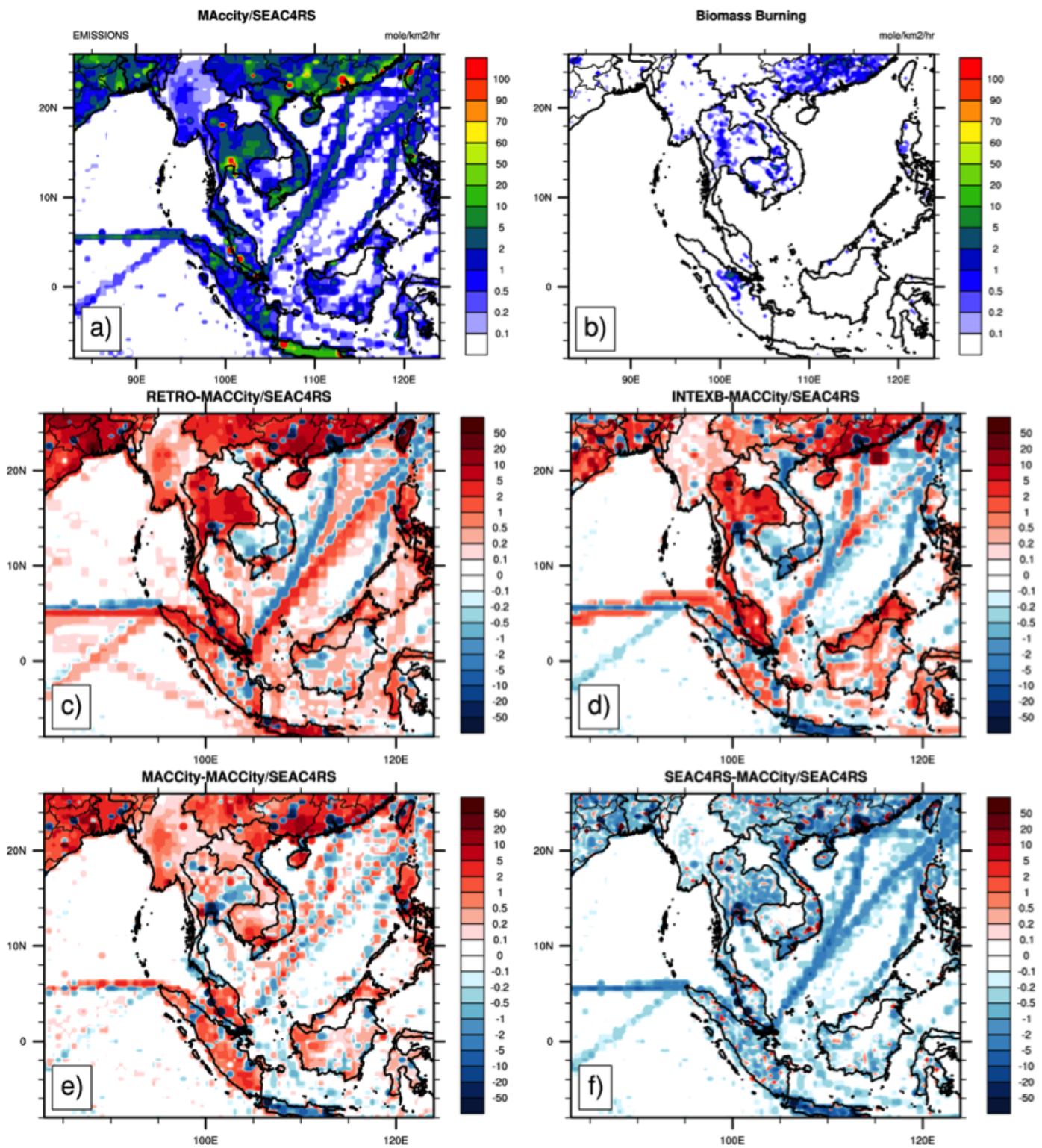

Figure 4. Nitrogen oxides emissions for December 2008 from different emission inventories: (a) MACCity-SEAC4RS, (b) biomass burning, (c) RETRO - MACCity-SEAC4RS, (d) INTEX-B - MACCity-SEAC4RS, (e) MACCity - MACCity-SEAC4RS, and (f) SEAC4RS MACCity-SEAC4RS.

mospheric Chemistry and Climate Model Intercomparison Project (ACCMIP) historical emissions data set (Lamarque et al., 2010). The goal of the MACCity emissions inventory is to support the IPCC-AR5 (Intergovernmental Panel for Climate Change Assessment Report 5), providing historical emissions from a variety of emission sectors (Table 1) on a decadal basis from 1960 to 2020, as well as for future emissions scenarios based on RCPs (Representation Concentration Pathways; van Vuuren et al., 2011). Anthropogenic emissions have been interpolated on a yearly basis between the base years 1990, 2000, 2005, and 2010. The MACCity emissions are estimated for 19 chemical species: CO, ethane, ethene, propane, propene, butane and higher alkanes, butene and higher alkenes, methanol, other alcohols, formaldehyde, other aldehydes, acetone, other ketones, total aromatics, ammonia, $\mathrm{NO}_{\mathrm{x}}, \mathrm{SO}_{2}, \mathrm{BC}$, and $\mathrm{OC}$, with spatial resolution of $0.5^{\circ} \times 0.5^{\circ}$. Because the 2000 MACCity emissions inventory does not have substantial biases compared to other emissions inventories, it is expected that the 2010 MACCity emissions inventory has uncertainties similar to those discussed 

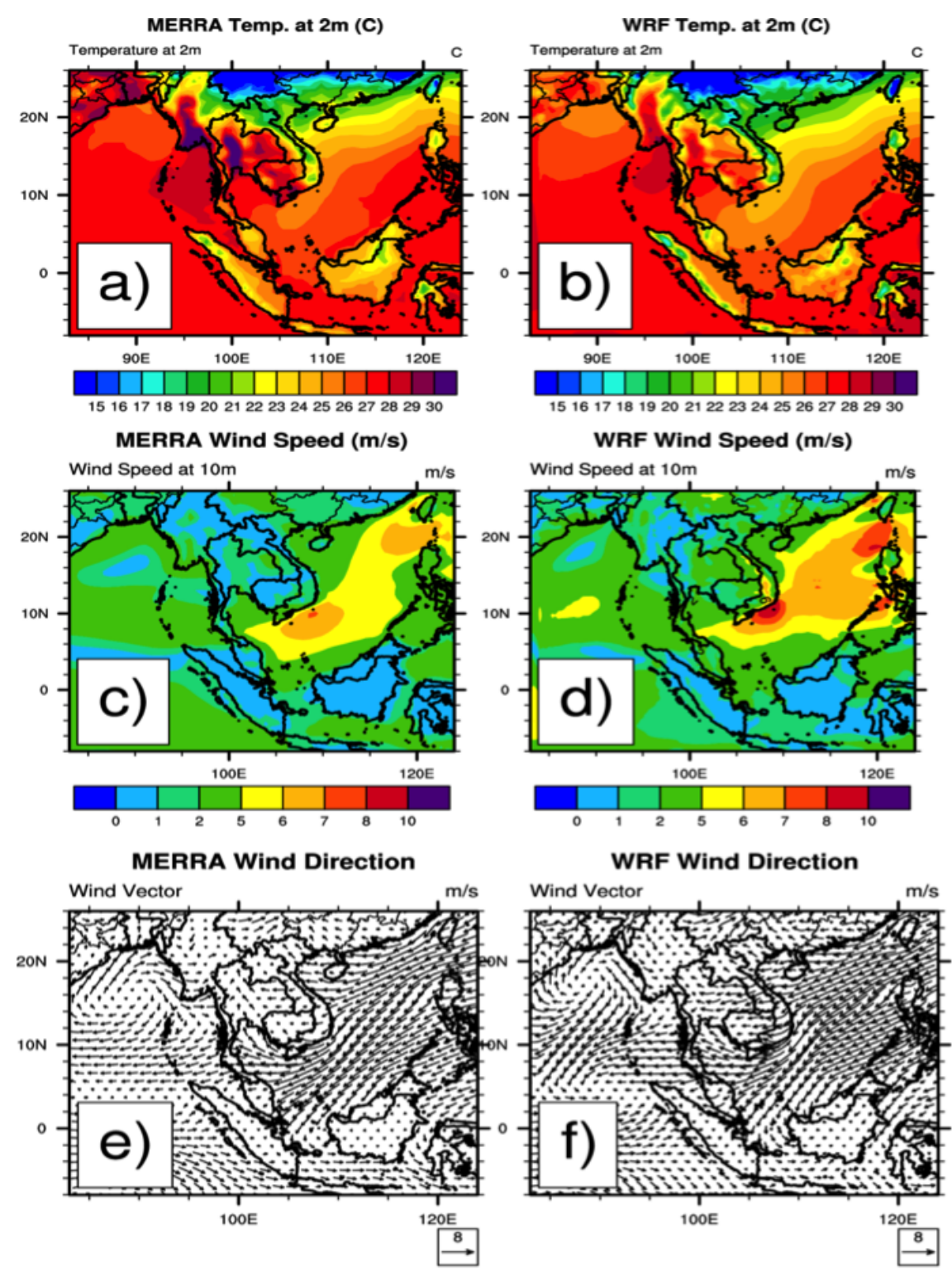

Locations of Observation

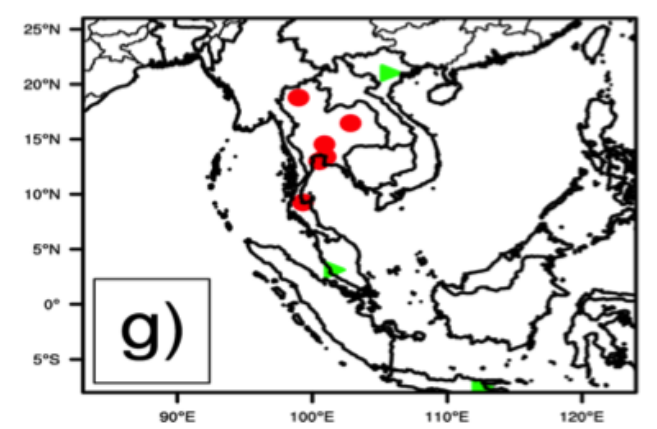

Figure 5. March 2008 monthly averaged (a) $2 \mathrm{~m}$ temperature $\left({ }^{\circ} \mathrm{C}\right)$ from MERRA, (b) $2 \mathrm{~m}$ temperature $\left({ }^{\circ} \mathrm{C}\right)$ from WRF, (c) $10 \mathrm{~m}$ wind speed $\left(\mathrm{m} \mathrm{s}^{-1}\right)$ from MERRA, (d) $10 \mathrm{~m}$ wind speed $\left(\mathrm{m} \mathrm{s}^{-1}\right)$ from WRF, (e) $10 \mathrm{~m}$ wind direction from MERRA, and (f) $10 \mathrm{~m} \mathrm{wind} \mathrm{direction} \mathrm{from}$ WRF. (g) Locations of ground-based $\mathrm{CO}$ and $\mathrm{O}_{3}$ measurements (red dot) and ozonesonde sites (green triangle) are marked. 
Table 1. Emission sectors used in the model simulations from each emission inventory.

\begin{tabular}{llll}
\hline RETRO & INTEX-B & MACCity & SEAC4RS \\
\hline 1. Power & 1. Power plant & 1. Energy production & 1. Residential \\
Generation & 2. Industry & and distribution & 2. Industry \\
2. Residential & 3. Residential & 2. Industry(combustion & 3. Power \\
3. Industrial & 4. Transportation & and non-combustion) & 4. Transport \\
combustion & & 3. Land transport & \\
4. Industrial & & 4. Maritime transport & \\
5. Extraction & & 6. Residential and & \\
distribution & & commercial & \\
of fossil fuels & & 7. Solvents & \\
6. Solvent use & & 8. Agriculture & \\
7. Road & 9. Agricultural waster & \\
transport & burning on fields & \\
8. Other mobile & 10. Waste & \\
sources & & \\
9. Waste & & & \\
treatment and & & & \\
disposal & & & \\
10. Agriculture and & & & \\
Landuse change & & & \\
\hline
\end{tabular}

by Lamarque et al. (2010) who did not find significant biases in their comparison of 2000 MACCity emissions with published emission estimates (e.g., RETRO and EDGAR). However, they estimate that these emissions have an uncertainty of about a factor of 2 based on Bond et al. $(2004,2007)$ and Smith et al. (2010). The uncertainty of the 2010 emissions was not reported. In this study, we use the 2010 emissions estimates from MACCity, which are based on the RCP8.5 scenario.

The SEAC4RS emissions inventory ( $\mathrm{Lu}$ and Streets, 2012), a regional anthropogenic emission data set prepared for the NASA SEAC4RS field campaign and for the Asia region, represents an update of the TRACE-P emissions (Streets et al., 2003). These emissions are appropriate for year 2012 and include four emissions sectors: residential, industry, power, and transportation (Table 1). There are 10 major chemical species, $\mathrm{CH}_{4}, \mathrm{CO}, \mathrm{NO}_{\mathrm{x}}, \mathrm{NMVOC}, \mathrm{CO}_{2}$, $\mathrm{SO}_{2}, \mathrm{PM}_{10}, \mathrm{PM}_{2.5}, \mathrm{BC}$, and $\mathrm{OC}$, with spatial resolution of $0.1^{\circ} \times 0.1^{\circ}$. Not only does this emissions inventory provide a finer resolution than the other inventories applied in this study, the SEAC4RS emissions data include an update of the Asia emission estimates using new energy use data and updated emission factors (both reflecting the year 2012), as well as the development of a new emission inventory for Southeast Asia using a technology-based methodology, which is the first detailed emission update for the region since TRACE-P. Similar to the INTEX-B inventory described above, the total NMVOC emissions were speciated to the individual VOC species of the MOZART-4 mechanism using fractions derived from the RETRO inventory.
In addition to the four inventories described above, we have conducted a simulation with a combined MACCitySEAC4RS emissions inventory, which replaces MACCity with the SEAC4RS emissions over Asia yet includes the MACCity ship emissions, which include international shipping, domestic shipping, and fishing. Note, that in the RETRO and INTEX-B inventories, ship emissions represent only international shipping. The ship emissions for RETRO, INTEX-B, and MACCity are listed in Table 2. In the MACCity emissions inventory, ship emissions account for $15 \%$ of the NO emissions and $0.8 \%$ of the $\mathrm{CO}$ emissions. To ensure consistency in the MACCitySEAC4RS simulation, the SEAC4RS emissions have been regridded from $0.1^{\circ} \times 0.1^{\circ}$ resolution to $0.5^{\circ} \times 0.5^{\circ}$. This regridding causes differences between the SEAC4RS-only and MACCity-SEAC4RS emissions outside the shipping regions in the model domain.

While both the RETRO and MACCity emission inventories have monthly temporal variability, the INTEX-B and SEAC4RS inventories are annual totals. A monthly profile was created from the RETRO emissions. The MACCity seasonal variation is very similar to RETRO for CO emissions, but does differ somewhat for NO emissions. The change of NO emissions from February (when we start the simulation) to March differs between these two inventories with little change in high NO emissions for the MACCity inventory and a $5 \%$ decrease in NO emissions for the RETRO inventory. While this is a small difference, the change in NO emissions could affect $\mathrm{O}_{3}$ production downwind of $\mathrm{NO}$ sources. To obtain the monthly profile for INTEX-A and SEAC4RS emissions, the fraction of the annual emissions assigned to 

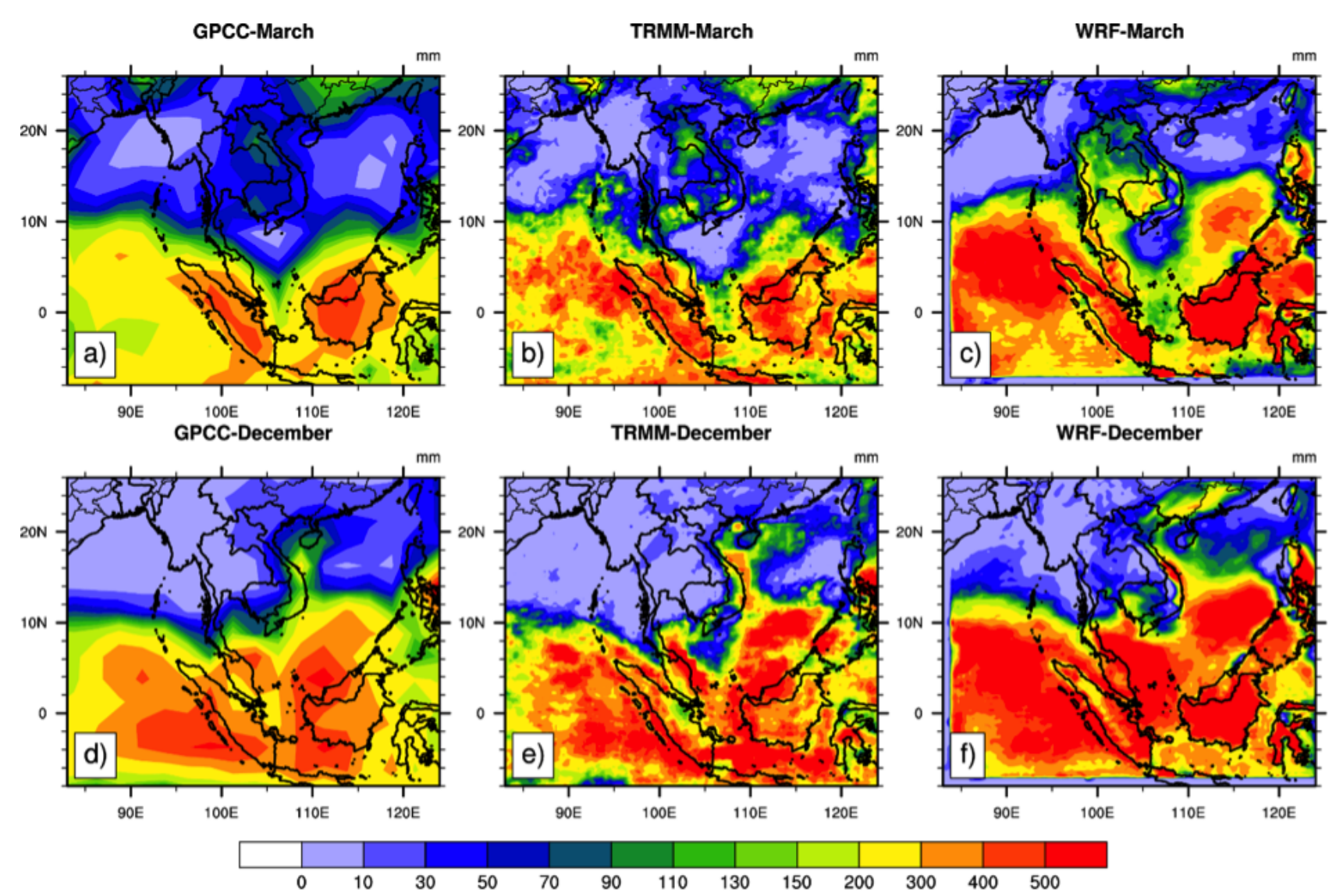

Figure 6. Accumulated precipitation (mm) (a) GPCC, March, (b) TRMM, March, (c) WRF, March (d) GPCC, December (e) TRMM, December, (f) WRF, December.

each month ( Frac $_{\text {Monthly }}$ ) was calculated from the ratio of the RETRO monthly emissions (RETRO Monthly) to the RETRO annual emissions $\left(\operatorname{RETRO}_{\text {Annual }}\right)$. The monthly fraction was then multiplied by the annual emissions of both the INTEX$B$ and SEAC4RS inventories to estimate the monthly emissions. This procedure is described by the following equations:

RETRO $_{\text {Annual }}=\sum_{i=1}^{12}$ RETRO $_{\text {Monthly }}$,

$\operatorname{Frac}_{\text {Monthly }}(i)=\frac{\text { RETRO }_{\text {Monthly }}(i)}{\text { RETRO }_{\text {Annual }}}$,

Emission $_{\text {Monthly }}(i)=\operatorname{Frac}_{\text {Monthly }}(i) \times$ Emission $_{\text {Annual }}$,

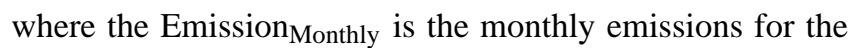

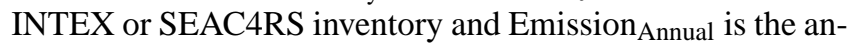
nual emissions from the INTEX or SEAC4RS inventory.

\subsection{Emission comparison}

The monthly emissions from the five different anthropogenic emissions inventories and the biomass-burning emissions calculated by the FINN model for $\mathrm{CO}$ and $\mathrm{NO}_{\mathrm{x}}$ are compared for both March and December in Fig. 1-4. The sum of these emissions over the entire model domain is listed in Table 2. In March, the biomass-burning sources dominate the emissions of $\mathrm{CO}$. The biomass burning occurs primarily over the Indochina peninsula and Southeast China where $\mathrm{CO}$ biomass emissions dominate the inventory. In March in Southeast Asia, $\sim 70 \%$ of the total $\mathrm{CO}$ emissions is from biomass burning and only $\sim 30 \%$ is from anthropogenic emissions. This partitioning is true for all the emission inventories applied in this study. In December, the biomass-burning emissions are much smaller.

Anthropogenic emissions of $\mathrm{CO}$ vary between emissions inventories, with RETRO and MACCity emissions having higher values, particularly in northeast India and Southeast China. Over the entire domain, the anthropogenic $\mathrm{NO}_{\mathrm{x}}$ emissions are quite similar between RETRO, INTEXB, MACCity, and MACCity-SEAC4RS emissions, but are much smaller in the SEAC4RS inventory, since this inventory alone does not include ship emissions. By comparing RETRO emissions to MACCity-SEAC4RS emissions, the total anthropogenic emissions in Southeast Asia decreased by $\sim 30 \%$ for $\mathrm{CO}$ and $\sim 13 \%$ for NO between 2000 and 2012 with 2010 ship emissions. 

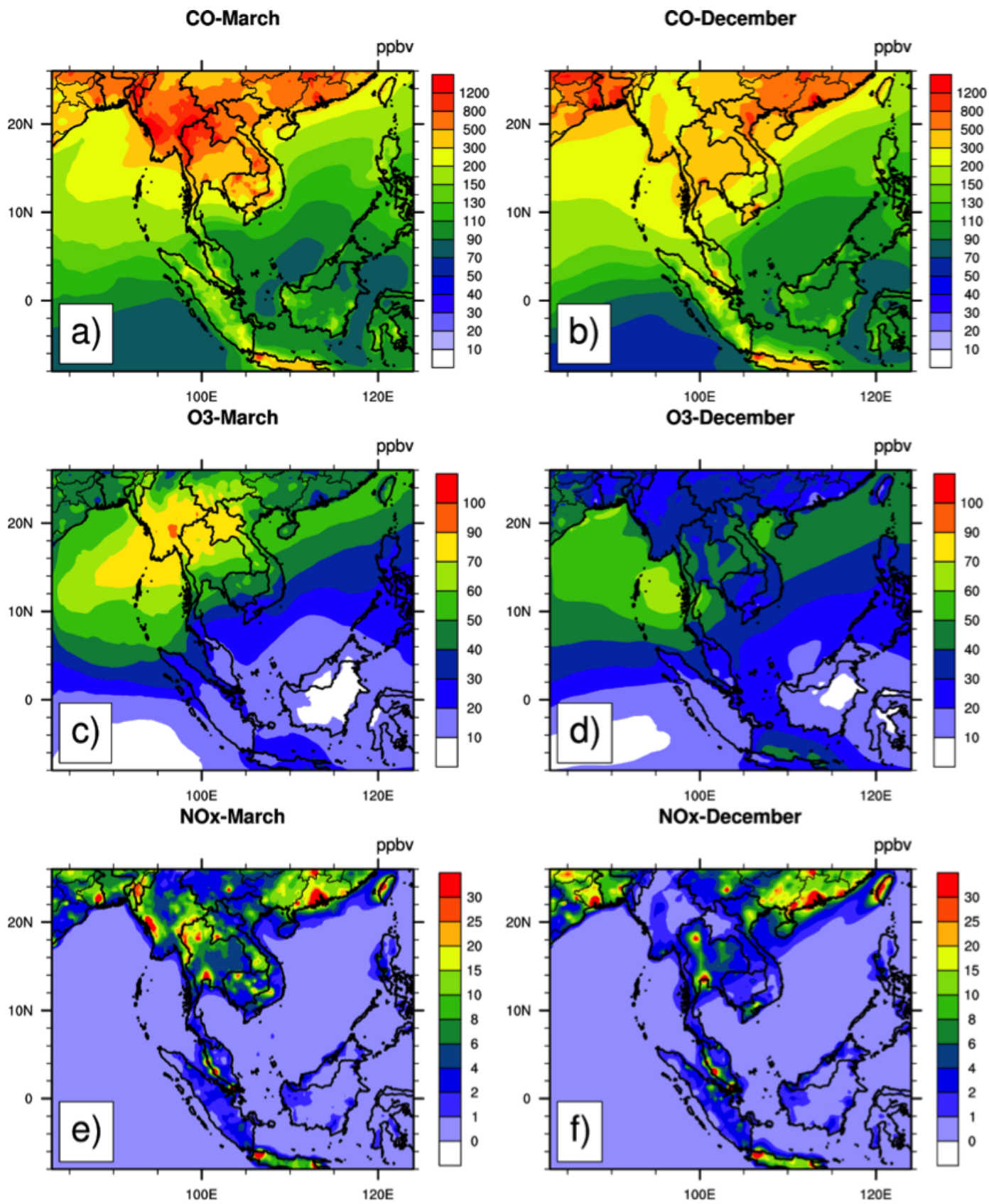

Figure 7. Monthly mean, surface mixing ratios for (a) and (b) $\mathrm{CO}$, (c) and (d) $\mathrm{O}_{3}$ (e) and (f) $\mathrm{NO}_{\mathrm{x}}$ predicted by WRF-Chem using the average from five emission inventories for March (left) and December (right panels) 2008.

Comparison of the total $\mathrm{CO}$ emissions from the various inventories across Southeast Asia (Table 2) shows that in March, the RETRO inventory is within $\pm 5 \%$ of the INTEX$\mathrm{B}$ and MACCity inventories, but is $\sim 20 \%$ greater than the MACCity-SEAC4RS and SEAC4RS inventories. In December, the CO MACCity-SEAC4RS inventory is $35 \%$ lower than the RETRO emissions inventory. The SEAC4RS NO emissions are substantially less $(\sim 45 \%)$ than the other inventories in both March and December because of the lack of ship emissions in the SEAC4RS inventory. NO emissions in the INTEX-B and MACCity inventories are similar to each other and $\sim 10 \%$ lower than the RETRO emissions. In December, the INTEX-B, MACCity, and MACCity-SEAC4RS NO emissions are similar and are $\sim 25 \%$ lower than the RETRO inventory.

The CO and NO emissions used in our study are larger than the REAS v1 emissions (Ohara et al., 2007) for our modeling domain (Table 2). The REAS v1 estimate in 


\section{Variations (\%)}
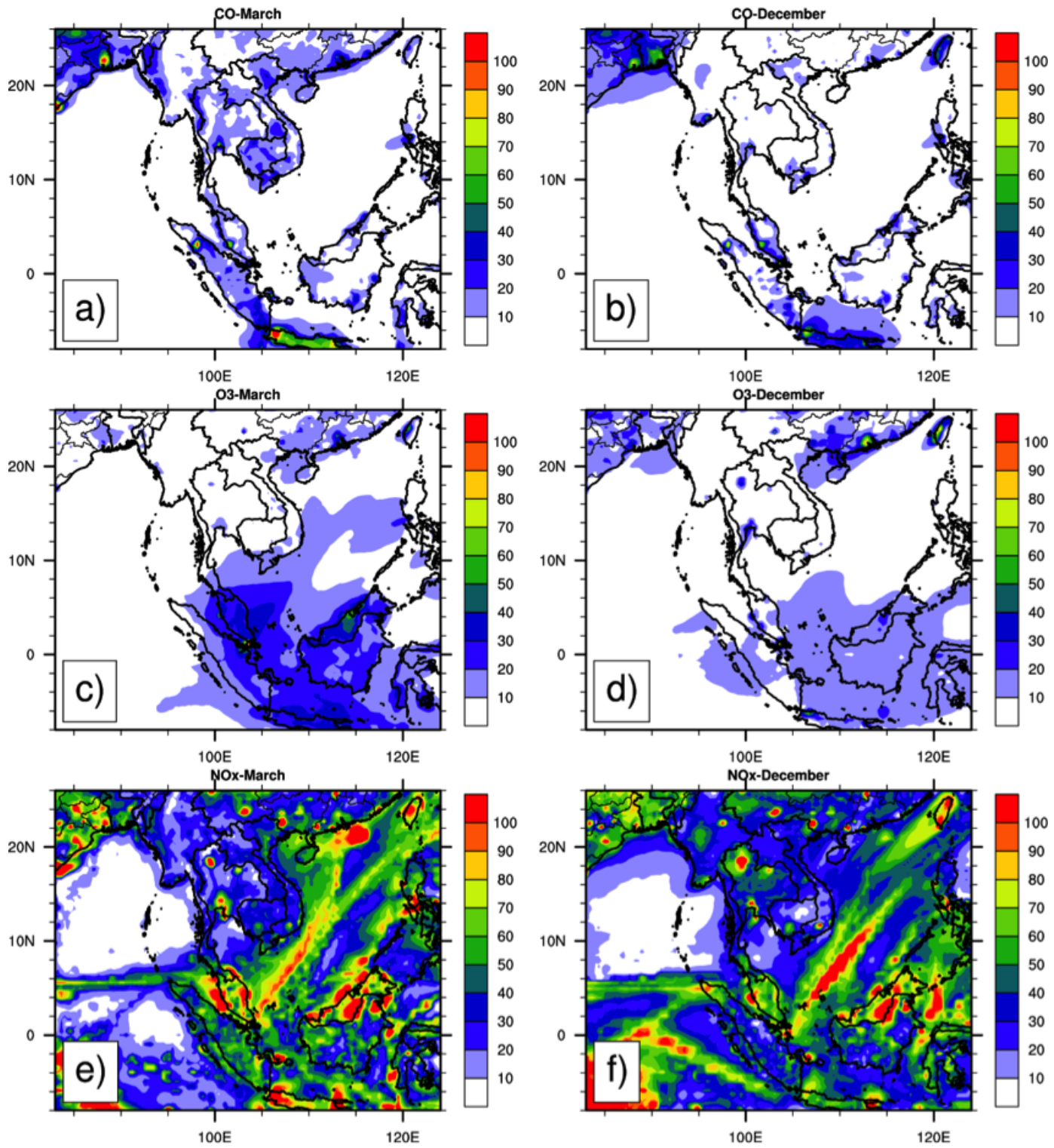

Figure 8. Variations of surface mixing ratios for (a) and (b) $\mathrm{CO}$, (c) and (d) $\mathrm{O}_{3}$ (e) and (f) $\mathrm{NO}_{\mathrm{x}}$ predicted by WRF-Chem using the averaged from five emission inventories for March (left) and December (right panels) 2008.

Table 2 comes from the Emissions of atmospheric Compounds and Compilation of Ancillary Data (ECCAD) web site (http://eccad.sedoo.fr) to obtain emission estimates for the same region as our model domain, which encompasses small regions of India and China that are not included in the Southeast Asia region denoted by Ohara et al. (2007). For our model domain the REAS v1 annual emissions are $91.4 \mathrm{Tg} \mathrm{yr}^{-1}$ for $\mathrm{CO}$ and $4.81 \mathrm{Tg} \mathrm{yr}^{-1}$ for $\mathrm{NO}_{\mathrm{x}}$. For the Southeast Asia region, Ohara et al. (2007) report in their Table 6 annual $\mathrm{CO}$ and $\mathrm{NO}_{\mathrm{x}}$ emissions of 54.5 and $3.77 \mathrm{Tg} \mathrm{yr}^{-1}$, respectively, but these exclude international aviation, international shipping, and open biomass burn- ing. The REAS v1 emissions are even greater than the TRACE-P, EDGAR 3.2, and IIASA (the International Institute for Applied Systems Analysis) CO emissions (34.0, 42.6, 39.8 $\mathrm{Tg} \mathrm{CO} \mathrm{yr}^{-1}$, respectively) but are more similar to TRACE-P, EDGAR 3.2, and IIASA NOx emissions (3.06, 3.91, $3.94 \mathrm{Tg} \mathrm{NO}_{\mathrm{x}} \mathrm{yr}^{-1}$, respectively) for Southeast Asia (Ohara et al., 2007) as well as REAS v2.1 (Kurakawa et al., 2013), which were $36.2 \mathrm{Tg} \mathrm{CO} \mathrm{yr}^{-1}$ and 3.00 $\mathrm{Tg} \mathrm{NO}_{\mathrm{x}} \mathrm{yr}^{-1}$. Thus, the emissions used here are larger than the REAS emissions inventories as well as other previous inventories. 

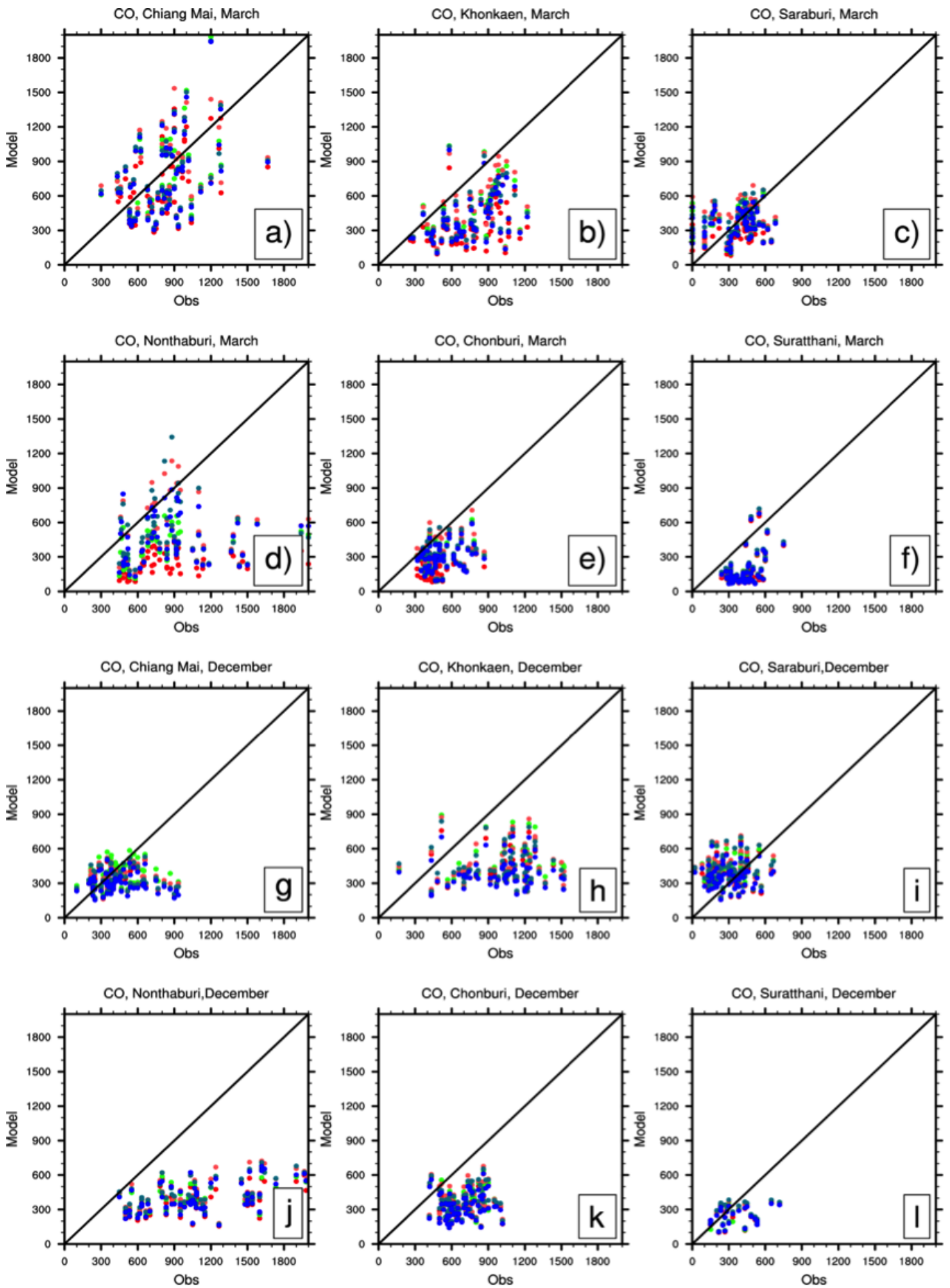

Figure 9. Scatterplots of 6-hourly daytime CO from WRF-Chem using different emissions inventories (red dots are RETRO emissions, teal dots are SEAC4RS, orange dots MACCity, green dots INTEX-B, and blue dots are combined MACCity and SEAC4RS) and ground-based observations for March and December.

\section{Data used for the model evaluation}

To evaluate the ability of the WRF-Chem model to represent the meteorology and chemical composition over Southeast
Asia during March and December 2008, the model results are evaluated with observations. The data used for the model evaluation are described here. 
Table 2. Summation of CO emissions and NO emissions (mole km ${ }^{-2} \mathrm{~h}^{-1}$ ) from all grids in the model domain for each month.

\begin{tabular}{lcccc}
\hline \multirow{2}{*}{ Emission Inventory } & \multicolumn{2}{c}{ E_CO $\left(\mathrm{mole} \mathrm{km}^{-2} \mathrm{~h}^{-1}\right)$} & \multicolumn{2}{c}{ E_NO $\left(\mathrm{mole} \mathrm{km}^{-2} \mathrm{~h}^{-1}\right)$} \\
\cline { 2 - 5 } & March & December & March & December \\
\hline RETRO-2000 & 410840 & 496860 & 30590 & 39320 \\
INTEX-B-2006 & 396170 & 406240 & 27410 & 29640 \\
MACCity-2010 & 436750 & 454250 & 27440 & 28280 \\
MACCity-SEAC4RS & 319420 & 320310 & 29810 & 30910 \\
SEAC4RS-2012 & 305542 & 300369 & 16610 & 17290 \\
Biomass Burning-2008 & 717940 & 58780 & 10220 & 700 \\
RETRO-Ship & 3404 & 3364 & 5097 & 5186 \\
INTEX-B-Ship & 5888 & 5785 & 3273 & 3301 \\
MACCity-Ship & 3569 & 3717 & 3980 & 5138 \\
REAS v1 ${ }^{\mathrm{a}}$-2000 & \multicolumn{2}{c}{282120} & & 13828 \\
\hline
\end{tabular}

a REAS v1 emissions are from the ECCAD web site (http://eccad.sedoo.fr) and are the annual emissions converted to hourly emissions assuming constant emissions for the year over the WRF-Chem model domain.

\subsection{Meteorology data description}

The predicted meteorology from the WRF simulations, which is the same for all model simulations, was evaluated by comparing $2 \mathrm{~m}$ temperature, $10 \mathrm{~m}$ winds, and precipitation with existing observations. The observations used for this evaluation include the Modern-Era Retrospective Analysis For Research And Applications (MERRA) products, the Tropical Rainfall Measuring Mission (TRMM) satellite data, and data from the Global Precipitation Climatology Center (GPCC).

The MERRA product (Rienecker et al., 2011) is generated using version 5.2.0 of the GEOS-5 DAS (Goddard Earth Observing System Model Data Assimilation System) with the model and analysis each at about $0.5^{\circ} \times 0.6^{\circ}$ resolution. MERRA has complete analysis of over 30 years (from 1979 to present) of data. The $2 \mathrm{~m}$ temperature and $10 \mathrm{~m}$ winds produced by the MERRA analysis system are hourly. However, the provided monthly averaged data were used here to evaluate the WRF results.

The main objective of the TRMM satellite (Huffman et al., 1997), which is a joint mission between NASA and Japan Aerospace Exploration Agency (JAXA), is to monitor rainfall in the tropics. We compare the WRF-Chem monthly surface rainfall to the TRMM product that is a combination of instruments, including the precipitation radar and TRMM microwave imager, allowing us to compare model results with the high-resolution data from the precipitation radar filled in by data from the TRMM Microwave Imager. The precipitation gauge analysis is used to correct any biases in the satellite data (Huffman and Bolvin, 2012).

Monthly precipitation from the GPCC data set (Rudolf et al., 2005a,b) is obtained from global station data that is gridded onto a $1^{\circ} \times 1^{\circ}$ global domain. The GPCC monthly precipitation product is based on anomalies from the climatological mean at each station. The anomalies are spatially interpolated by using a modified version of the robust empirical interpola- tion method SPHEREMAP. The method constitutes a spherical adaptation (Willmott et al., 1985) of Shepard's empirical weighting scheme (Shepard, 1968; Schneider et al., 2011).

\subsection{Chemistry data description}

Observations from four measurement platforms are used to evaluate the WRF-Chem predictions of $\mathrm{CO}, \mathrm{O}_{3}$, and $\mathrm{NO}_{2}$ : a ground-based monitoring network in Thailand, ozonesondes in the Southeast Asia region, version 6 Measurement of Pollution In the Troposphere (MOPITT) satellite instrument, and the Ozone Monitoring Instrument (OMI) satellite instrument. The ground-based chemistry observations in Thailand are provided by the Thai Pollution Control Department (PCD). The Thai PCD monitors the hourly surface concentrations of five chemical species: $\mathrm{O}_{3}, \mathrm{CO}, \mathrm{NO}_{2}$, $\mathrm{SO}_{2}$, and $\mathrm{PM}_{10}$ at six locations (Fig. 5g). The measurement sites in Thailand are located in urban areas and therefore are dominated by urban (especially motor vehicles) emissions. These data are measured by using the reference method or equivalent methods. Almost all $\mathrm{O}_{3}$ observation instruments are from Teledyne Advanced Pollution Instrumentation Model 400 (http://www.teledyne-api.com/ products/400e.asp). The instrument has a lower detection limit of $0.6 \mathrm{ppbv}$ and a precision of $1 \%$. Almost all $\mathrm{CO}$ observation instruments are from Teledyne Advanced Pollution Instrumentation Model 300 (http://www.teledyne-api. com/products/300e.asp), which has a lower detection limit of $40 \mathrm{ppbv}$ and a precision of $0.5 \%$. The PCD measurements periodically have missing data, but the missing data are only $\sim 15 \%$ of the time.

The SHADOZ ozonesonde network (Thompson et al., 2012) was initiated to provide vertical profiles of $\mathrm{O}_{3}$ in the tropics for satellite data verification, model evaluation, and insights into tropical chemistry and dynamics. SHADOZ has collected more than $3000 \mathrm{O}_{3}$ profiles from 14 sites in tropical and subtropical regions using balloon-borne electrochemical 

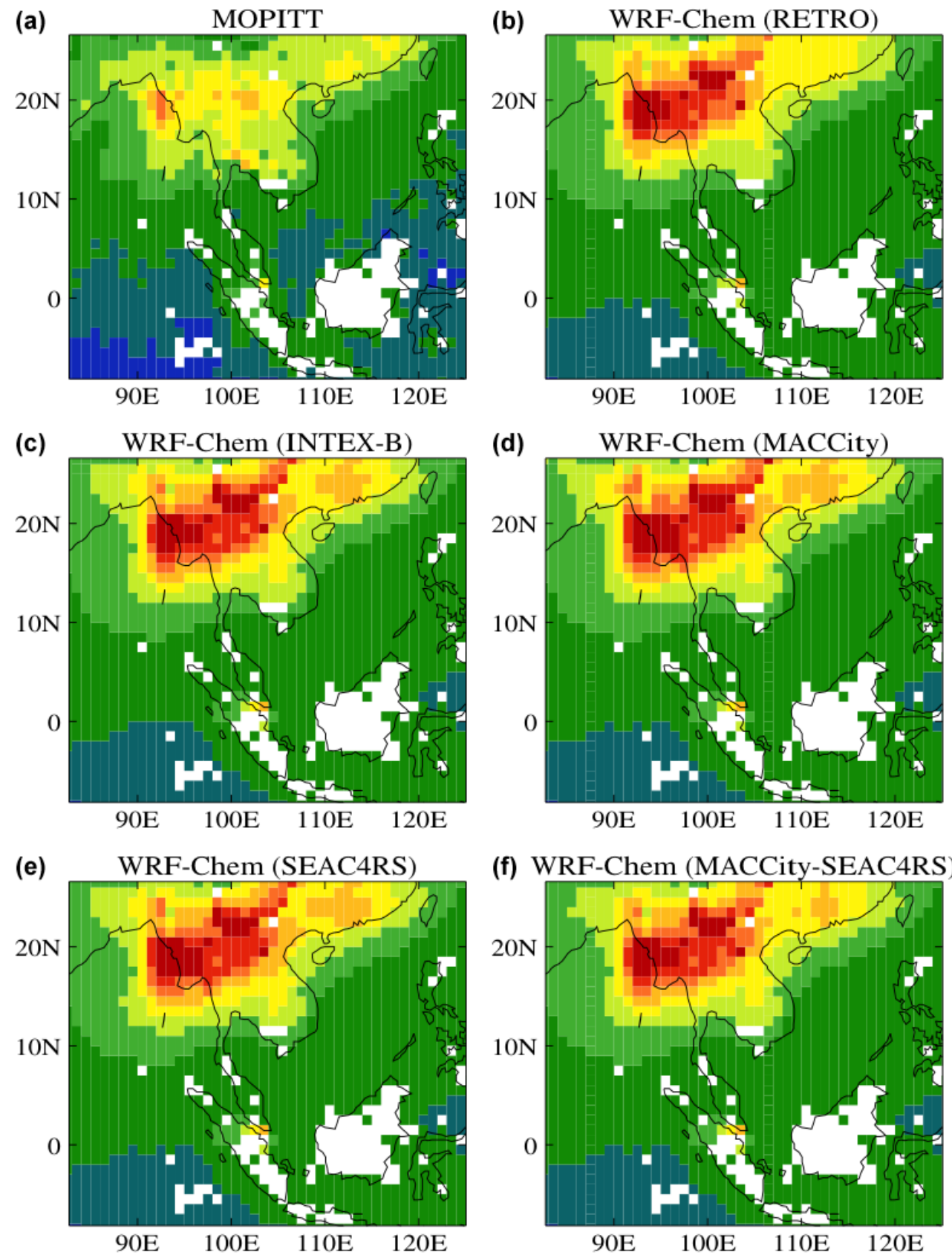

(f) WRF-Chem (MACCity-SEAC4RS)


Figure 10. Carbon monoxide from WRF-Chem and MOPITT in March (a) MOPITT (b) WRF-Chem simulation with RETRO emission inventory, (c) WRF-Chem simulation with INTEX-B emission inventory, (d) WRF-Chem simulation with MACCity emission inventory, (e) WRF-Chem simulation with SEAC4RS emission inventory, (f) WRF-Chem simulation with MACCity-SEAC4RS emission inventory.

concentration cell (ECC) $\mathrm{O}_{3}$ detectors flown with standard radiosondes. It is estimated that the accuracy and precision of the $\mathrm{O}_{3}$ measurement is $5 \%$, but biases can be found with individual stations. Ozonesondes from three stations (Kuala Lumpur, Malaysia; Hanoi, Vietnam; and Watukosek, Java)
(Fig. $5 \mathrm{~g}$ ) are used in the model evaluation presented in this manuscript. Total $\mathrm{O}_{3}$ column at these stations can be $5-10 \%$ lower than total $\mathrm{O}_{3}$ measured by the OMI satellite instrument (Thompson et al., 2012). 

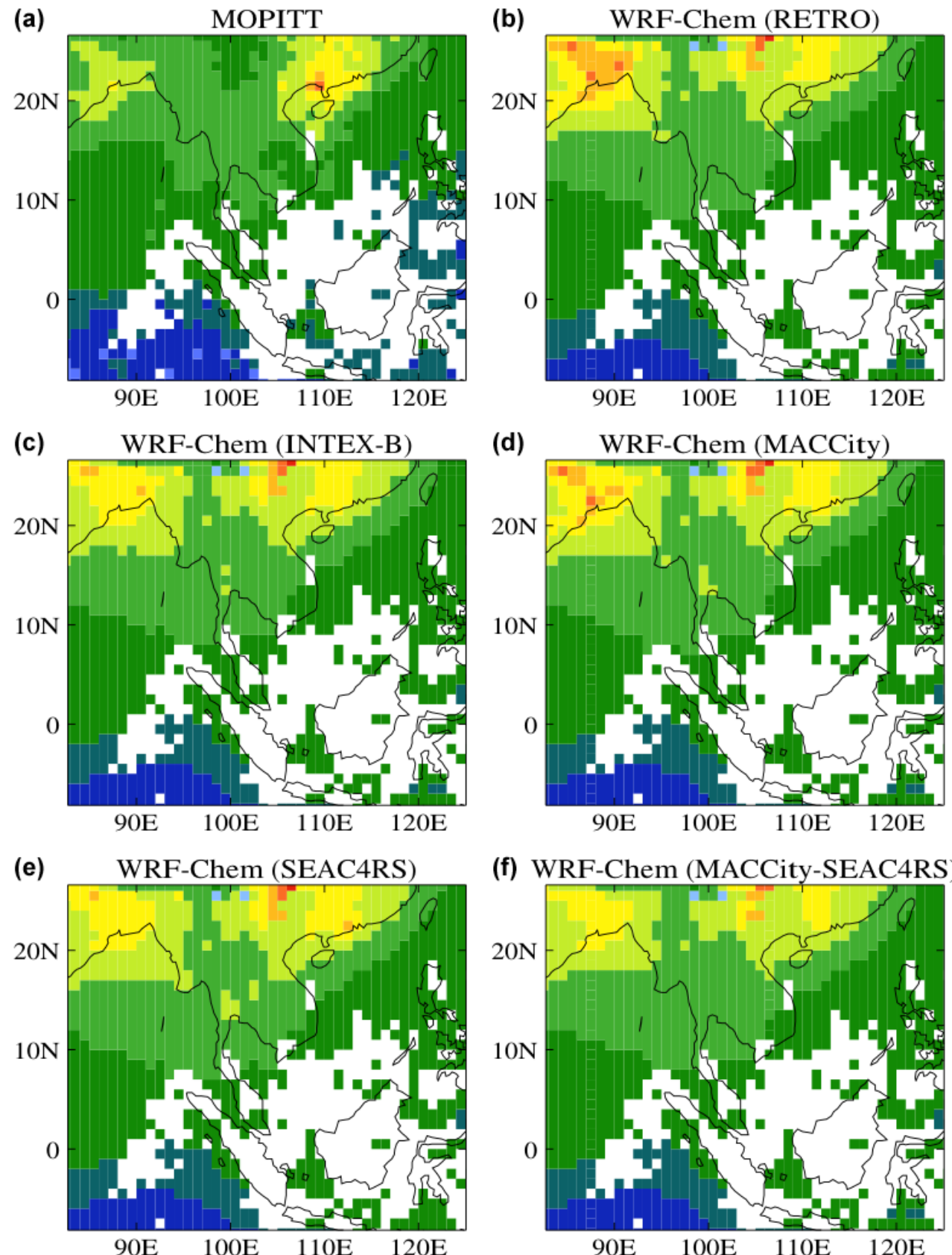

(f) WRF-Chem (MACCity-SEAC4RS)
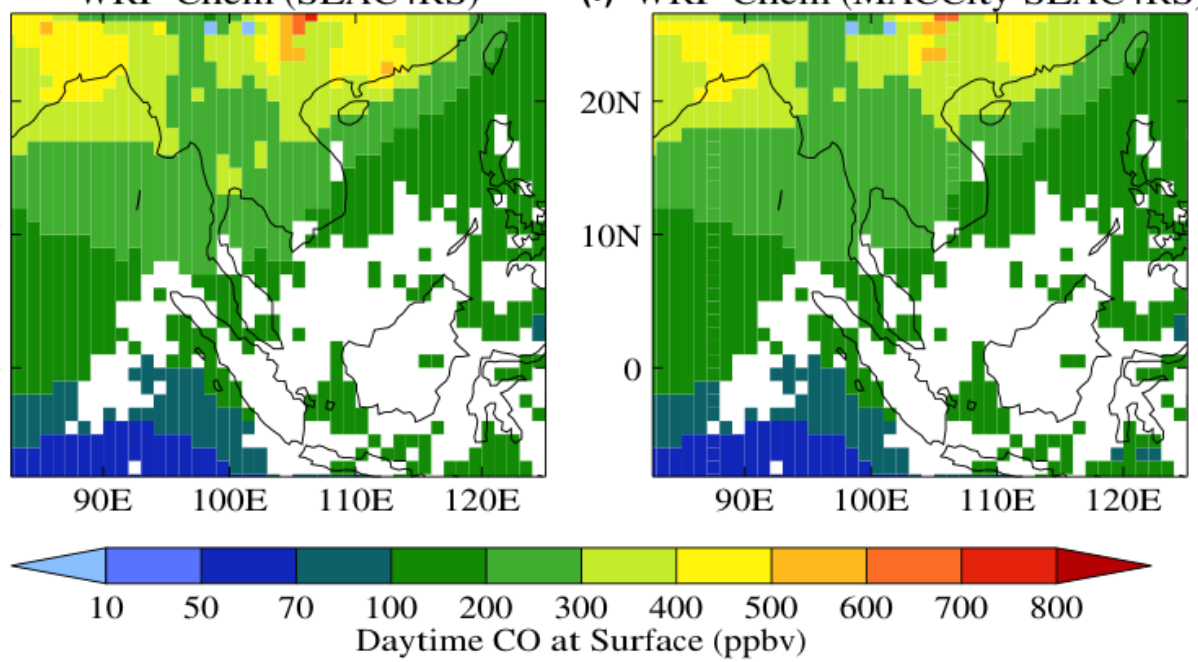

Figure 11. Same as Fig. 10 but for December.

Satellite observations are quite valuable for model evaluation, but require careful interpretation to be used quantitatively. In many cases (as in MOPITT CO and OMI $\mathrm{NO}_{2}$ ) the retrieved mixing ratios or column densities can be expressed as a linear combination of the true atmospheric profile $(\boldsymbol{x})$ and a priori information $\left(\boldsymbol{x}_{\mathrm{a}}\right)$, balanced according to the av- eraging kernels (A) (I is the identity matrix):

$\boldsymbol{x}_{\text {ret }}=\mathbf{A} x+(\mathbf{I}-\mathbf{A}) \boldsymbol{x}_{\mathrm{a}}$.

The averaging kernels represent the sensitivity of the retrievals to the actual concentration profiles, and vary in time and space depending on the temperature profile, the thermal 

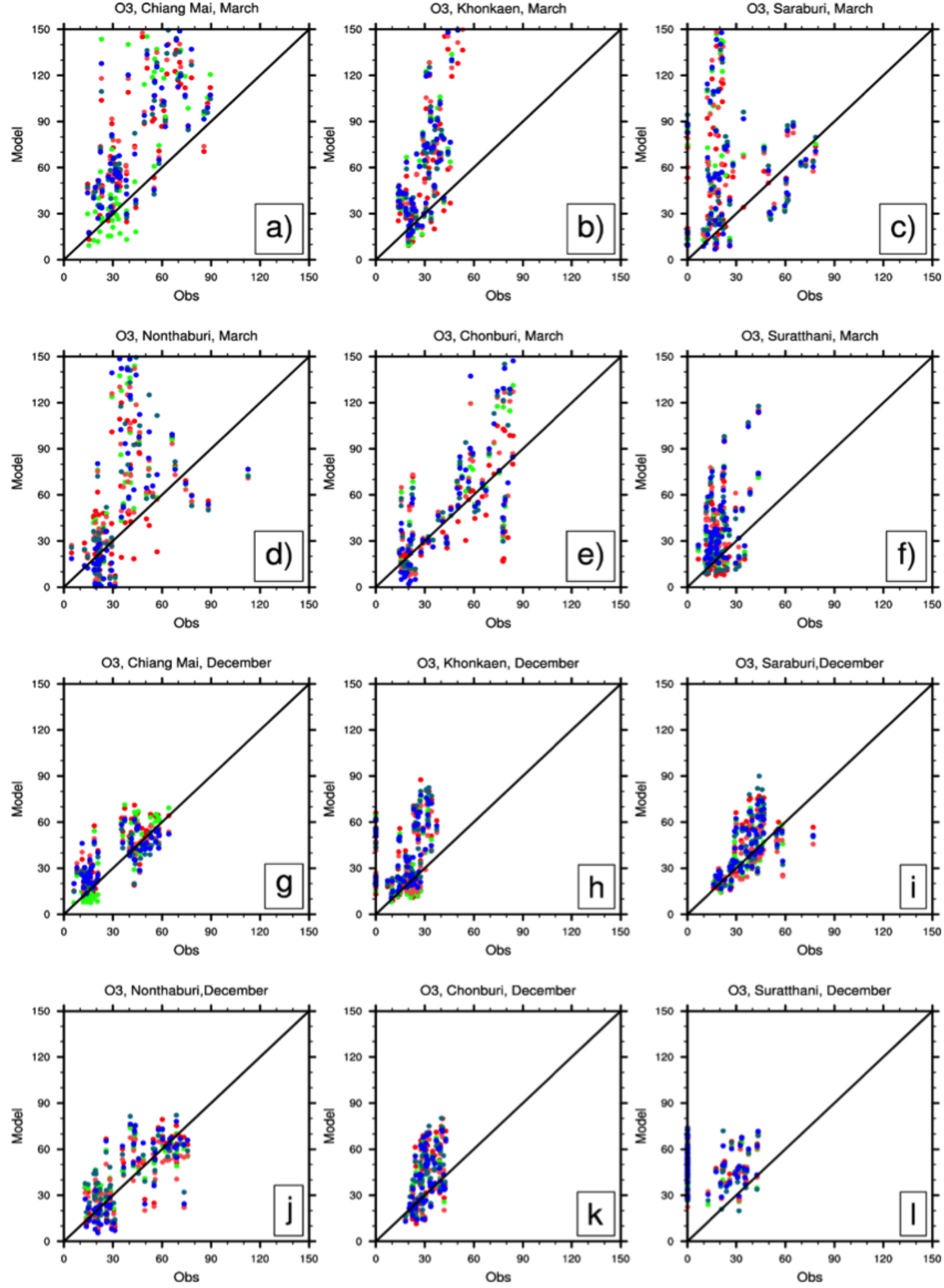

Figure 12. Scatterplots of 6-hourly daytime $\mathrm{O}_{3}$ from WRF-Chem using different emissions inventories (red dots are RETRO emissions, teal dots are SEAC4RS, orange dots MACCity, green dots INTEX-B, and blue dots are combined MACCity and SEAC4RS) and ground-based observations for March and December. 
Watukosek Java, O3 Mixing Ratio, March 13, 2008

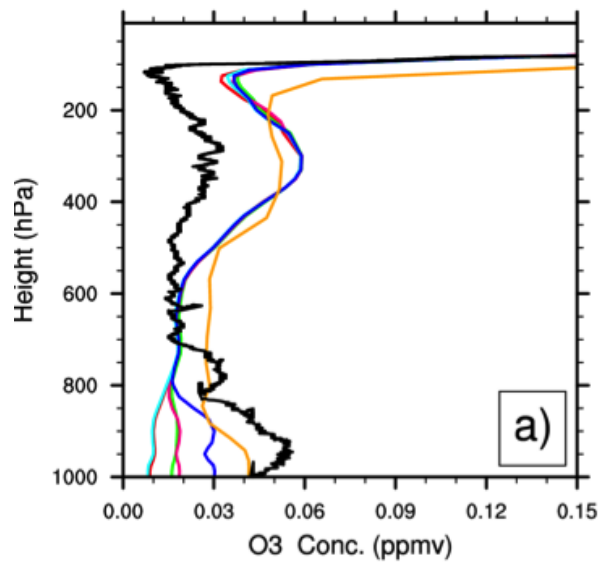

Kuala Lumpur, O3 Mixing Ratio, March 17, 2008

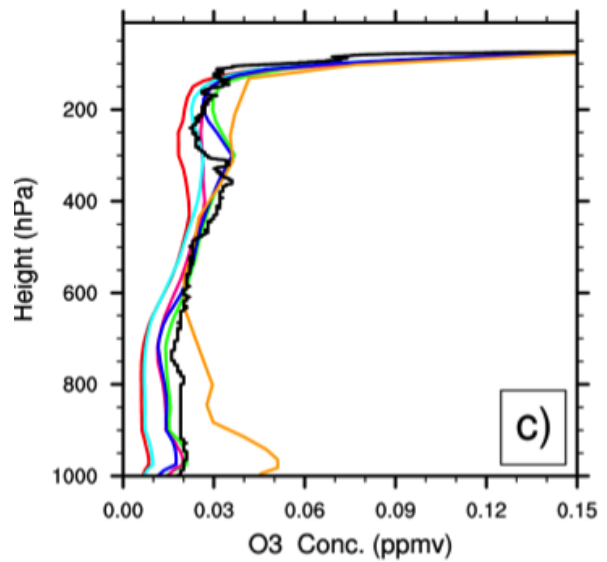

Hanoi, O3 Mixing Ratio, March 12, 2008

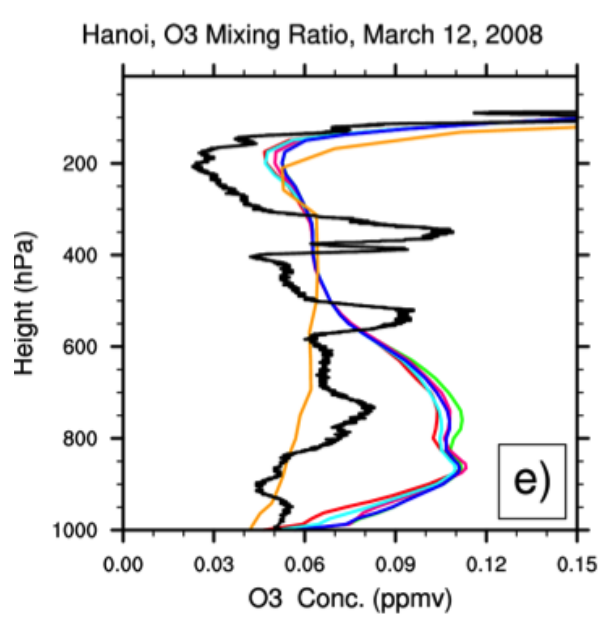

Watukosek Java, O3 Mixing Ratio, December 11, 200

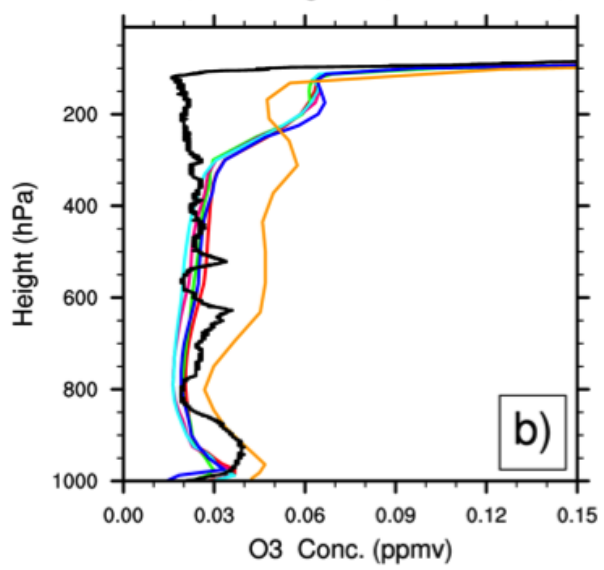

Kuala Lumpur, О3 Mixing Ratio, December 17, 2008

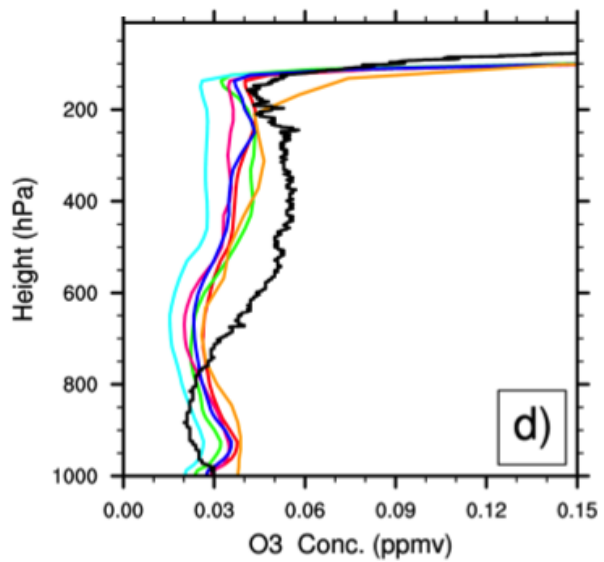

Figure 13. $\mathrm{O}_{3}$ vertical profiles from WRF-Chem, MOZART4, and ozonesondes at three SHADOZ ozonesonde locations for (a) WatukosekJava, Indonesia in March, (b) Watukosek-Java, Indonesia in December, (c) Kuala Lumpur, Malaysia in March, (d) Kuala Lumpur, Malaysia in December, and (e) Hanoi, Vietnam in March. Note that there are no SHADOZ data at Hanoi during December 2008.

contrast between air and surface temperatures, the concentration profile, and surface emissivity.
The new versions of MOPITT data (versions 5 and 6; Deeter et al. 2011, 2012, 2013; Worden et al., 2010), which we used in this paper, have improved near-surface $\mathrm{CO}$ re- 
trievals over version 4. The V6 MOPITT uses both nearinfrared and thermal-infrared observations simultaneously to enhance the retrieval sensitivity of $\mathrm{CO}$ in the lower troposphere. This feature is important to air quality analyses and studies of CO sources. The V5 MOPITT surface-level CO validation shows biases on the order of a few percent, and V6 is very similar (Deeter et al., 2012).

The OMI Level-3 Global Gridded $\mathrm{NO}_{2}$ data product, archived at the NASA Goddard Earth Sciences Data and Information Service Center (GES DISC), has a spatial resolution of about $13 \mathrm{~km} \times 24 \mathrm{~km}$ at nadir in normal operational mode. OMI measures the backscattered radiation over the $0.27-0.5 \mu \mathrm{m}$ wavelength range to obtain the total column of trace species, such as $\mathrm{NO}_{2}, \mathrm{O}_{3}$, formaldehyde, $\mathrm{SO}_{2}$ and aerosols. The tropospheric $\mathrm{NO}_{2}$ column retrieval algorithm follows Bucsela et al. (2006) who use the DOAS (differential optical absorption spectroscopy) methodology, air mass factors, and typical $\mathrm{NO}_{2}$ profiles from chemical transport models to obtain the vertical column density. The OMI tropospheric $\mathrm{NO}_{2}$ column data have been shown to have a good correlation with INTEX-B aircraft measurements (Boersma et al., 2008). Good agreement of OMI tropospheric $\mathrm{NO}_{2}$ column has also been found with MAX-DOAS (multi-axis differential optical absorption spectroscopy) ground-based measurements (Kramer et al., 2008). However, some recent studies have suggested that the OMI retrieval has a positive bias of 0-30 \% (e.g., Boersma et al., 2009; Zhou et al., 2009). To evaluate $\mathrm{NO}_{2}$ from model results, we compare the tropospheric column of $\mathrm{NO}_{2}$ from the OMI Level-3 Global Gridded $\mathrm{NO}_{2}$ data product with WRF-Chem $\mathrm{NO}_{2}$ columns that have been adjusted using the averaging kernel and a priori information (following Eq. 4) provided with the data product (e.g., Emmons et al., 2004).

\section{Model results and evaluation}

\subsection{Meteorology evaluation}

Monthly averaged $2 \mathrm{~m}$ temperature, wind speed and direction are compared to the MERRA reanalysis data set. In general, the model-predicted temperature agrees well with the MERRA output (Fig. 5) for the March 2008 simulation, although some regions, e.g., Indochina peninsula, have 2$3{ }^{\circ} \mathrm{C}$ lower temperatures than the monthly averaged reanalysis output. The WRF-predicted wind speed pattern is similar to the MERRA output for March. However, the wind speed is overpredicted in the South China Sea by $\sim 2 \mathrm{~m} \mathrm{~s}^{-1}$. The wind direction agrees quite well with MERRA output (Fig. 5e, f). For December 2008 (not shown), the simulated $2 \mathrm{~m}$ temperature, $10 \mathrm{~m}$ wind speed and wind direction, in general, also agree well with the MERRA output; however, the temperature is slightly underpredicted over land and the wind speed is overpredicted over the South China Sea. The low bias in temperature and high bias in wind speed can impact the prediction of chemical species mixing ratios. For example, the chemical reactions likely will proceed at a slightly lower rate (because of their dependence on temperature) resulting in formation of products further away from the source. Additionally, biogenic emissions may be underpredicted, since these emissions increase with increasing temperatures and a low bias in temperature can lead to lower emissions.

WRF reasonably predicts the precipitation pattern in March (Fig. 6a-c) when compared to TRMM and GPCC data. Low precipitation is observed over the coast of Burma, the northern part of the South China Sea, and the tip of the Indochina peninsula, and high precipitation is predicted near the equator over the oceans, Malaysian peninsula, and Indonesia. However, the WRF results overestimate precipitation near the equator by 10 to $100 \mathrm{~mm}$ for March. In December (Fig. 6d-f), WRF also overpredicts the magnitude of precipitation over the water, but shows reasonable agreement north of $10^{\circ} \mathrm{N}$ especially over land. The precipitation in this region is dominated by rain from convection, which is controlled by mesoscale processes. The WRF simulations presented here have a $36 \mathrm{~km}$ horizontal resolution, and at this resolution, the model relies on a cumulus parameterization to produce the rain. Due to the coarse model resolution for a region with plenty of tropical convection, a situation which is notoriously difficult to represent in models, the poor prediction of precipitation near the equator is not unexpected. Koo and Hong (2010) also found oceanic convection to be overpredicted by the WRF model. However, over land, where the chemical predictions of this study are evaluated, the WRF precipitation has better agreement with observations. As a consequence of the higher precipitation predicted by WRF, WRF-Chem may overpredict the removal of soluble trace gases (e.g., nitric acid), thereby affecting the photochemistry in the region.

\subsection{Evaluation of chemistry}

\subsubsection{Ensemble surface means and variations}

To show the distribution of the monthly mean surface mixing ratios for $\mathrm{CO}, \mathrm{O}_{3}$, and $\mathrm{NO}_{\mathrm{x}}$ in March and December, the WRF-Chem results from all five simulations (with different emissions inventories) have been averaged giving an ensemble mean (Fig. 7). In general, surface-level $\mathrm{CO}$ and $\mathrm{NO}_{\mathrm{x}}$ mixing ratios have the highest values over the land regions and the lowest values over the ocean near the equator. By comparing the model results from March (high biomassburning emissions) to those from December (low biomassburning emissions), the influence of biomass-burning emissions can be seen for all three species. $\mathrm{CO}$ mixing ratios are $>500$ ppbv over Burma and northern Thailand during March compared to 200-500 ppbv during December. Monthly averaged $\mathrm{O}_{3}$ mixing ratios, which reach $70-90 \mathrm{ppbv}$, are the largest during March over the regions where biomass burning is occurring and downwind of these emissions. With a 


\section{Monthly NO2 Total Column (molecule/cm2), March}

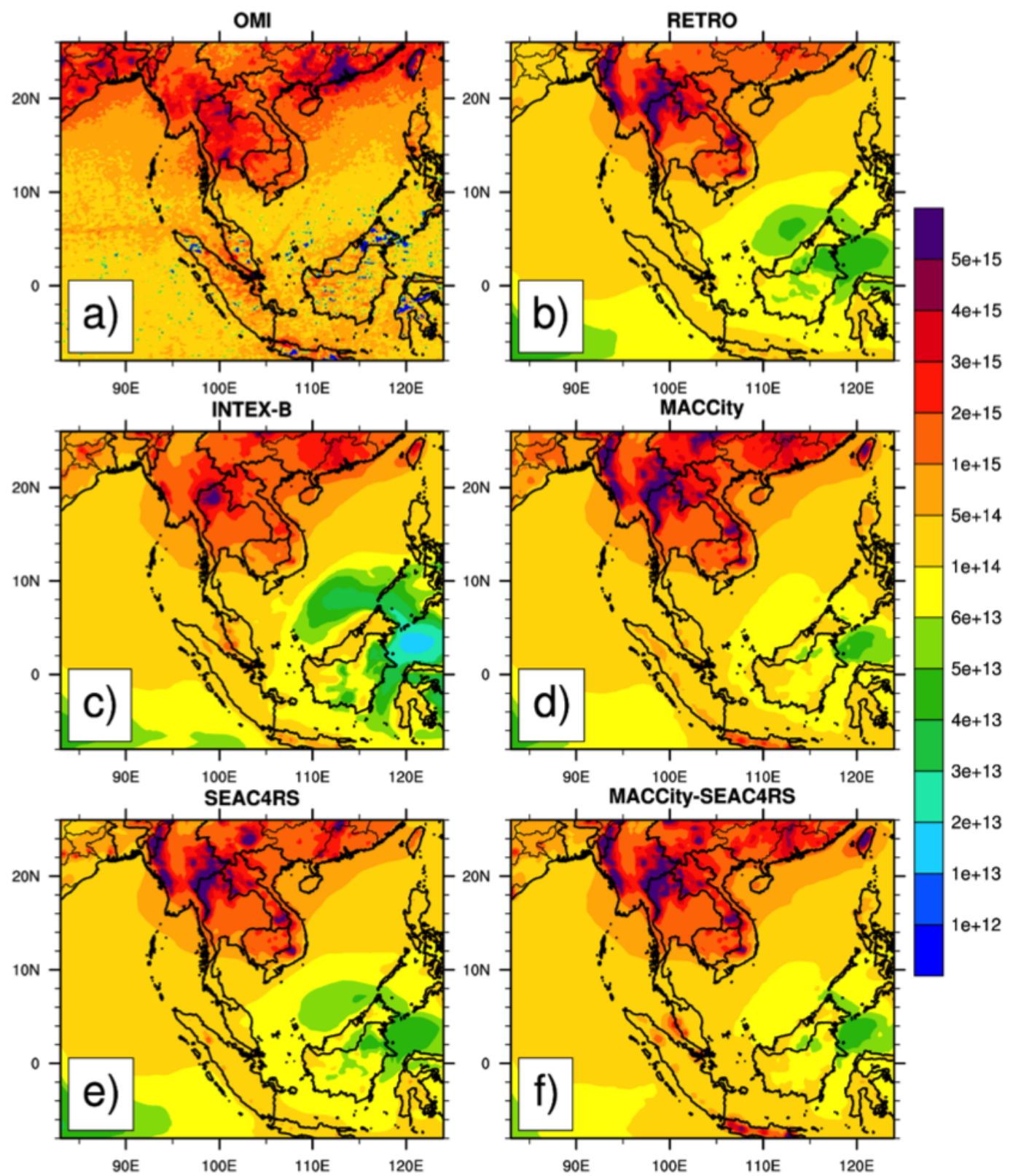

Figure 14. March 2008 monthly $\mathrm{NO}_{2}$ total column (a) OMI, (b) WRF-Chem + RETRO, (c) WRF-Chem + INTEX-B, (d) WRF-Chem + MACCity, (e) WRF-Chem + SEAC4RS, and (f) WRF-Chem + MACCity-SEAC4RS

shorter lifetime, high $\mathrm{NO}_{\mathrm{x}}$ mixing ratios of 4-30 ppbv are confined to regions close to the $\mathrm{NO}_{\mathrm{x}}$ sources.

The variation, which is defined as the standard deviation of the five simulations, in the predicted monthly averaged surface mixing ratios of $\mathrm{CO}, \mathrm{O}_{3}$, and $\mathrm{NO}_{\mathrm{x}}$ across the five simulations is highlighted in Fig. 8. Because we conducted each simulation with the same meteorology and biomass-burning emissions, the primary cause for the variations are the differences in the anthropogenic emissions. CO mixing ratios vary across simulations by $<20 \%$, but variations of $\sim 30-60 \%$ are found near Bangladesh and Indonesia for both March and December. $\mathrm{O}_{3}$ mixing ratios have up to $30 \%$ variation near the tip of the Malaysian peninsula and near Indonesia, but have much smaller variability elsewhere. Mixing ratios of $\mathrm{NO}_{\mathrm{x}}$ have the most variation among the simulations. The 70$100 \%$ variations for $\mathrm{NO}_{\mathrm{x}}$, especially over the South China Sea, are from the differences in ship emissions from each inventory. There are also high $\mathrm{NO}_{\mathrm{x}}$ variations in several cities 


\section{Monthly NO2 Total Column (molecule/cm2), December}
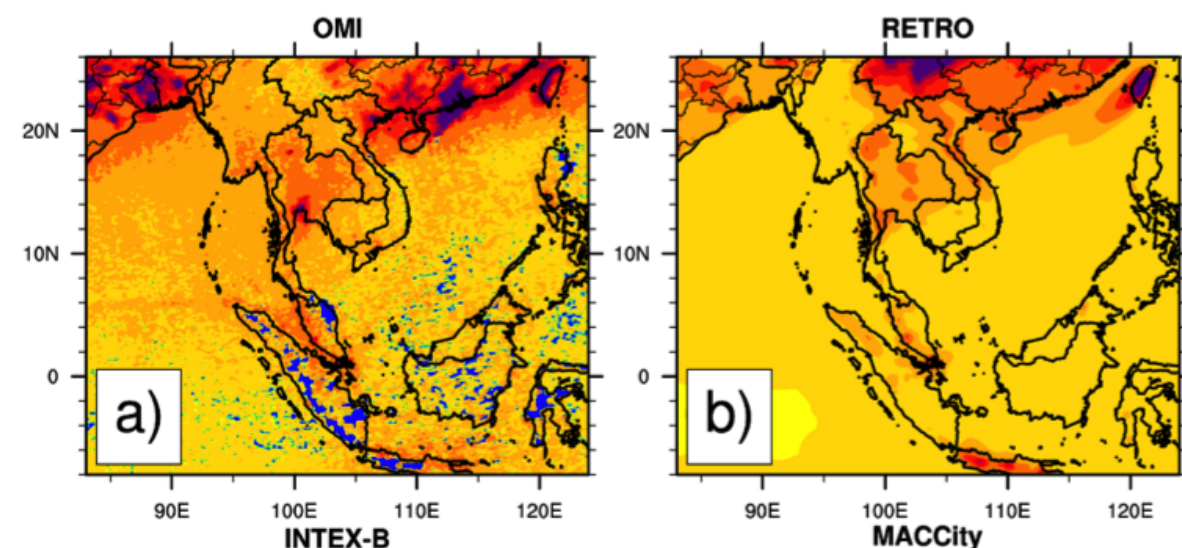

$5 e+15$

$4 e+15$
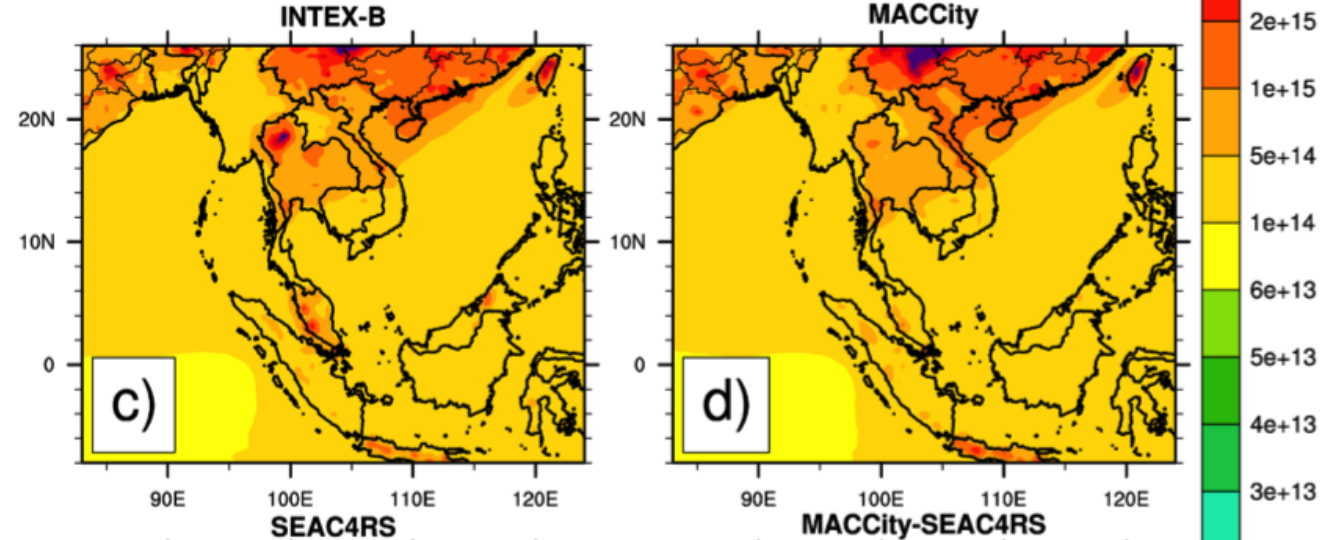

$5 e+14$
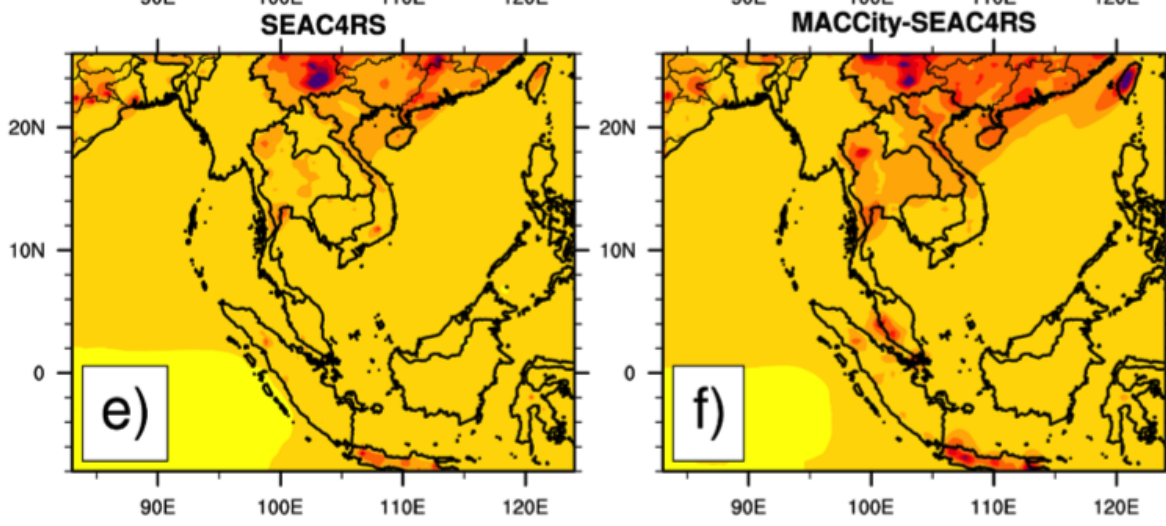

$1 e+14$

$6 e+13$

$5 e+13$

$4 e+13$

Figure 15. Same as Fig. 19 but for December.

as seen by the locally high values in Fig. 8e and $\mathrm{f}$, due to different emission strengths in each inventory and to missing emission sectors in some inventories (e.g., shipping emissions in the SEAC4RS inventory).

\subsubsection{CO evaluation}

The 6-hourly daytime (00:00, 06:00, 12:00 UTC) CO mixing ratios from WRF-Chem with each of the five inventories are compared to observations from the six ground-site measurements: Chiang Mai (CM) in northwest Thailand, Khon
Kaen (KK) in eastern Thailand, Nonthaburi (NTB) in the Bangkok metropolitan region, Saraburi (SRB) just north of Bangkok, Chonburi (CB) southeast of Bangkok, and Surat Thani (SRT) in the southern peninsula (Fig. 5g). These sites are located in urban environments with background conditions ranging from high biomass burning in northern Thailand to more marine conditions in southern Thailand. For March when biomass-burning emissions are a large source of $\mathrm{CO}$, the WRF-Chem simulations agree well with the monthly mean mixing ratio for Chiang-Mai in northwest Thailand and 
Table 3. Monthly-average correlation coefficients $(r)$ of daytime (00:00, 06:00, 12:00 UTC) CO.

\begin{tabular}{|c|c|c|c|c|c|c|c|c|c|c|c|c|}
\hline \multirow[t]{2}{*}{$\begin{array}{l}\text { Emission } \\
\text { Inventories }\end{array}$} & \multicolumn{2}{|c|}{$\mathrm{CM}$} & \multicolumn{2}{|c|}{ KK } & \multicolumn{2}{|c|}{ SRB } & \multicolumn{2}{|c|}{ NTB } & \multicolumn{2}{|c|}{ CBR } & \multicolumn{2}{|c|}{ SRT } \\
\hline & Mar & Dec & Mar & Dec & Mar & Dec & Mar & Dec & Mar & Dec & Mar & Dec \\
\hline RETRO & 0.49 & 0.13 & 0.35 & 0.10 & 0.27 & 0.15 & 0.40 & 0.31 & 0.48 & 0.15 & 0.52 & 0.03 \\
\hline INTEX-B & 0.51 & 0.14 & 0.42 & 0.20 & 0.17 & 0.17 & 0.33 & 0.38 & 0.44 & 0.17 & 0.58 & 0.03 \\
\hline MACCity & 0.50 & 0.14 & 0.45 & 0.10 & 0.11 & 0.19 & 0.26 & 0.33 & 0.43 & 0.19 & 0.55 & 0.003 \\
\hline SEAC4RS & 0.48 & 0.15 & 0.42 & 0.04 & 0.09 & 0.18 & 0.21 & 0.33 & 0.42 & 0.18 & 0.52 & 0.01 \\
\hline $\begin{array}{l}\text { MACCity/ } \\
\text { SEAC4RS }\end{array}$ & 0.48 & 0.15 & 0.41 & 0.07 & 0.12 & 0.14 & 0.26 & 0.33 & 0.44 & 0.14 & 0.54 & 0.004 \\
\hline
\end{tabular}

Table 4. Monthly-average biases of daytime (00:00, 06:00, 12:00 UTC) carbon monoxide.

\begin{tabular}{|c|c|c|c|c|c|c|c|c|c|c|c|c|}
\hline \multirow[t]{2}{*}{$\begin{array}{l}\text { Emission } \\
\text { Inventories }\end{array}$} & \multicolumn{2}{|c|}{$\mathrm{CM}$} & \multicolumn{2}{|c|}{ KK } & \multicolumn{2}{|c|}{ SRB } & \multicolumn{2}{|c|}{ NTB } & \multicolumn{2}{|c|}{ CBR } & \multicolumn{2}{|c|}{ SRT } \\
\hline & Mar & Dec & Mar & Dec & Mar & Dec & Mar & Dec & Mar & Dec & Mar & Dec \\
\hline RETRO & -104 & -147 & -396 & -581 & -219 & -314 & -721 & -770 & -253 & 23 & -267 & -89 \\
\hline INTEX-B & -16 & -114 & -316 & -529 & -150 & -283 & -662 & -747 & -203 & 46 & -234 & -109 \\
\hline MACCity & -18 & -112 & -292 & -530 & -116 & -263 & -636 & -733 & -195 & 60 & -238 & -112 \\
\hline SEAC4RS & -22 & -107 & -324 & -548 & -129 & -267 & -645 & -734 & -197 & 58 & -234 & -120 \\
\hline $\begin{array}{l}\text { MACCity/ } \\
\text { SEAC4RS }\end{array}$ & -47 & -157 & -35 & -601 & -165 & -328 & -674 & -785 & -218 & 10 & -243 & -93 \\
\hline
\end{tabular}

Chonburi in southeast Thailand (Fig. 9), with moderate correlation coefficients (Table 3 ) of $r^{2}=0.48$ to 0.51 . However, WRF-Chem generally underpredicts $\mathrm{CO}$ at the other stations, especially Nonthaburi. In December, the predicted 6-hourly daytime surface $\mathrm{CO}$ for all simulations is much less than the observations, with the exception of the Chonburi site. The large underprediction is reflected by the bias calculation (Table 4). Part of the underprediction is a result of the coarse model resolution $(36 \mathrm{~km})$, which cannot capture the highly variable emissions and high $\mathrm{CO}$ concentrations in an urban setting where the measurement site is located. However, the underprediction of $\mathrm{CO}$ could also be due to low anthropogenic emissions (discussed further in Section 5), a high planetary boundary layer height, which would cause dilution of surface mixing ratios, and/or missing chemistry in the model such as heterogeneous chemistry. Mao et al. (2013) suggest uptake of $\mathrm{HO}_{2}$ to aerosols undergo reaction with transition metal ions to convert $\mathrm{HO}_{2}$ to $\mathrm{H}_{2} \mathrm{O}$, removing hydrogen oxides from the atmosphere. They show that this proposed mechanism decreases $\mathrm{OH}$ at the surface, as simulated by the GEOS-Chem model, and consequently increases $\mathrm{CO}$ mixing ratios by $20-30$ ppbv. While a $20-30$ ppbv increase in $\mathrm{CO}$ over Thailand will not remove the high $\mathrm{CO}$ bias in our simulation, this heterogeneous chemistry may explain some of the underprediction of $\mathrm{CO}$. When comparing the $\mathrm{CO}$ concentrations from the different WRF-Chem simulations with the measurements in Thailand, we find the different WRFChem results to be quite similar. An examination of the cor- relation coefficients (Table 3 ) reveals that these values are quite similar from simulation to simulation. This can be due in part to the fact that none of the emission inventories are specific to the modeled time period. However, a paired difference test (Kruskal and Wallis, 1952) shows that there are statistical differences for CO among the different emission inventories at Khon Kaen, Saraburi, Nonthaburi, and Chonburi for both March and December and for Chiang Mai for December. The variability in the biases of the modeled CO mixing ratios (Table 4) also suggests that the different emission inventories are causing the different $\mathrm{CO}$ mixing ratios between the model simulations. Because the simulation using RETRO emissions, especially for March, has larger biases than the other simulations, the more recent $\mathrm{CO}$ emission inventories either better represent the emissions in general or are more similar to what the emissions were for 2008 .

The modeled CO surface mixing ratios are compared to the MOPITT V6 gridded Level 3 near-surface CO retrievals to evaluate the modeled spatial distribution (Figs. 10 and 11). The MOPITT V6 data (Deeter et al., 2011, 2012, 2013; Worden et al., 2010), used in this paper, has improved nearsurface CO retrievals. This improvement is accomplished by using near-infrared and thermal-infrared observations simultaneously to enhance the retrieval sensitivity of $\mathrm{CO}$ in the lower troposphere. WRF-Chem is able to capture well the patterns of high CO over Southeast Asia and Southern China in March (Fig. 10), but overpredicts CO over northern Thailand and Burma. These regions of high $\mathrm{CO}$ coincide with the 


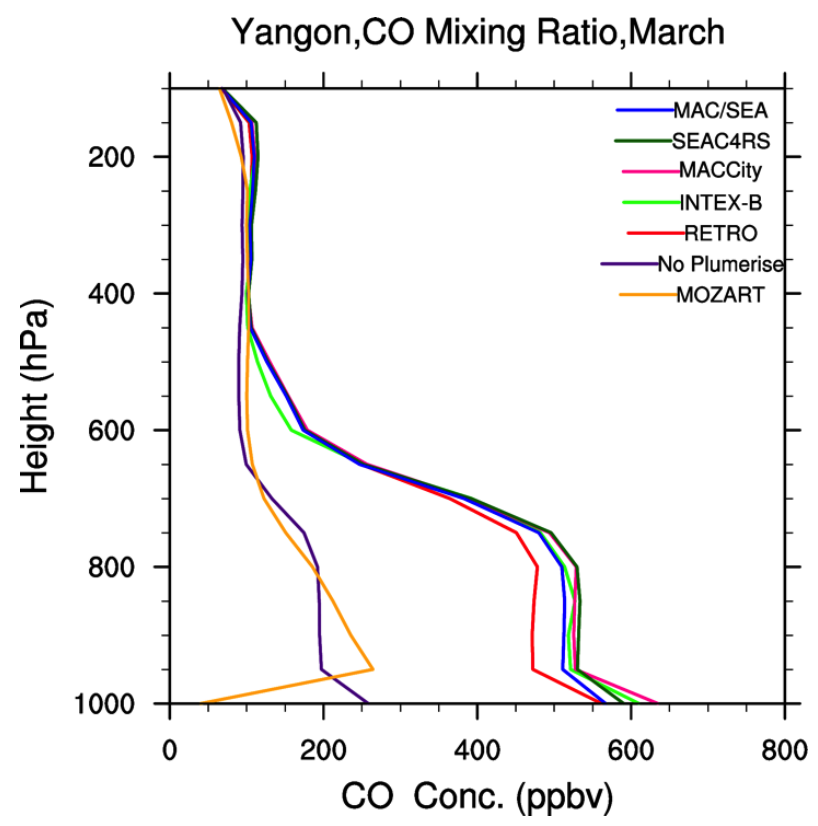

Figure 16. March monthly averaged CO vertical profiles at Yangon, Burma. WRF-Chem results with the plumerise feature of biomassburning emissions are given for the MACCity-SEAC4RS emissions case (blue line), SEAC4RS emissions (dark green line), MACCity emissions (red line), INTEX-B emissions (green line), and RETRO emissions (dark red line). The MOZART global model results are shown as the gold line. WRF-Chem results without the plumerise feature (i.e., biomass-burning emissions injected into the lowest model level) are shown as the purple line.

location of biomass burning, indicating the FINN fire emissions are too high in this region. The predicted $\mathrm{CO}$ mixing ratios are similar in magnitude to MOPITT over the Malay and southern Indochina peninsulas. For December when biomass burning is less important, the general spatial pattern of $\mathrm{CO}$ is represented by WRF-Chem for all the simulations (Fig. 11). The modeled CO in December is generally higher than MOPITT, particularly in the regions of the highest mixing ratios in southern China and easternmost India.

\subsection{3 $\mathrm{O}_{3}$ evaluation}

Scatterplots of the 6-hourly daytime $\mathrm{O}_{3}$ mixing ratios compared to the measurements at the six ground sites show that $\mathrm{O}_{3}$ is generally overpredicted for each of the different emission inventories for both March and December (Fig. 12) by up to $100 \mathrm{ppbv}$. Locations that showed good agreement for CO (e.g., Chiang Mai in March) have very poor agreement for $\mathrm{O}_{3}$. Despite the large scatter of model results for $\mathrm{O}_{3}$ (Fig. 12), the correlation coefficients are generally 0.5 and higher (Table 5) indicating that the model captures the $\mathrm{O}_{3}$ trend well, but has a high bias. WRF-Chem $\mathrm{O}_{3}$ biases (Table 6) range from -1 to 40 ppbv with MACCity and MACCity-SEAC4RS having the highest bias at Chiang Mai. In December (Fig. 12), the model-observation agreement is generally better than in March, although WRF-Chem tends to overpredict $\mathrm{O}_{3}$, especially at Khon Kaen and Saraburi in northeastern and central Thailand. In general, the comparison of the model results among the different emission inventories shows fairly similar results for $\mathrm{O}_{3}$ mixing ratios, correlation coefficients, and biases. The correlation coefficients among simulations mostly vary by $<0.1$, suggesting that the different anthropogenic emission inventories produce very little variation in modeled $\mathrm{O}_{3}$. A paired difference test (Kruskal and Wallis, 1952) of these surface $\mathrm{O}_{3}$ mixing ratios shows that there are not any statistical differences for $\mathrm{O}_{3}$ among the different emission inventories. Likewise, variation among the monthly mean $\mathrm{O}_{3}$ biases among the different simulations are $<15 \mathrm{ppbv}$ and mostly $<7 \mathrm{ppbv}$. The higher $\mathrm{O}_{3}$ bias in March compared to December, especially in Chiang Mai where there are large biomass-burning sources (Amnuaylojaroen and Kreasuwun, 2012), suggests that biomass-burning emissions are more uncertain than anthropogenic emissions.

The $\mathrm{O}_{3}$ vertical profiles resulting from the WRF-Chem simulations are compared to SHADOZ ozonesondes and MOZART4 model results at three locations (Hanoi, Vietnam; Watukosek-Java, Indonesia; and Kuala Lumpur, Malaysia) (Fig. 13). Both Hanoi and Watukosek-Java are near the WRFChem model domain boundaries (Fig. 5g). At WatukosekJava in March, the WRF-Chem prediction is low below the $700 \mathrm{hPa}$ level and too high above $600 \mathrm{hPa}$ (Fig. 13a), while the MOZART4 prediction is more similar to observations near the surface. In December, the WRF-Chem results agree well with the observations at Watukosek-Java from the surface to $300 \mathrm{hPa}$ (Fig. 13c). Above $300 \mathrm{hPa}$, the model overpredicts the $\mathrm{O}_{3}$ mixing ratios until it reaches the stratosphere. At Kuala Lumpur, the WRF-Chem results have very good agreement with $\mathrm{O}_{3}$ observations for March (Fig. 13b), while the MOZART4 results are high compared to the observations below the $600 \mathrm{hPa}$ level. In December at Kuala Lumpur, the observations are higher than the model results in the free troposphere (Fig. 13d). The free troposphere mixing ratios are likely from outside the domain where MOZART4 results are used as boundary conditions. The $\mathrm{O}_{3}$ measurements from Hanoi, a subtropical location, show multiple layers of $\mathrm{O}_{3}$ in the free troposphere with the lowest $\mathrm{O}_{3}$ values of $20 \mathrm{ppbv}$ occurring at $200 \mathrm{hPa}$ for the March time period (Fig. 13e). The WRF-Chem and MOZART4 results are not able to replicate the layering structure, but the WRF-Chem results do have high $\mathrm{O}_{3}$ values from 900 to $600 \mathrm{hPa}$, while MOZART4 $\mathrm{O}_{3}$ remains below $60 \mathrm{ppbv}$ throughout the troposphere. Neither model is able to predict the $20 \mathrm{ppbv}$ minimum $\mathrm{O}_{3}$ at $200 \mathrm{hPa}$. There is very little difference between the WRF-Chem results from the simulations with different emission inventories for Hanoi and Watukosek-Java, except for near the surface at Watukosek-Java in March. At Kuala Lumpur, there is much more variation between model results with different emission inventories. $\mathrm{O}_{3}$ from the SEAC4RS emissions inventory simulation is less than the $\mathrm{O}_{3}$ from the other simulations and has the worst agreement with observations at Kuala Lumpur. 
Table 5. Monthly-average correlation coefficients of daytime (00:00, 06:00, 12:00 UTC) $\mathrm{O}_{3}$.

\begin{tabular}{|c|c|c|c|c|c|c|c|c|c|c|c|c|}
\hline \multirow[t]{2}{*}{$\begin{array}{l}\text { Emission } \\
\text { Inventories }\end{array}$} & \multicolumn{2}{|c|}{$\mathrm{CM}$} & \multicolumn{2}{|c|}{ KK } & \multicolumn{2}{|c|}{ SRB } & \multicolumn{2}{|c|}{ NTB } & \multicolumn{2}{|c|}{ CBR } & \multicolumn{2}{|c|}{ SRT } \\
\hline & Mar & Dec & Mar & Dec & Mar & Dec & Mar & Dec & Mar & Dec & Mar & Dec \\
\hline RETRO & 0.69 & 0.84 & 0.68 & 0.34 & 0.56 & 0.50 & 0.47 & 0.71 & 0.11 & 0.52 & 0.49 & 0.16 \\
\hline INTEX-B & 0.74 & 0.89 & 0.72 & 0.33 & 0.70 & 0.48 & 0.45 & 0.72 & 0.05 & 0.56 & 0.44 & 0.09 \\
\hline MACCity & 0.68 & 0.78 & 0.71 & 0.33 & 0.69 & 0.48 & 0.44 & 0.68 & 0.02 & 0.55 & 0.43 & 0.08 \\
\hline SEAC4RS & 0.70 & 0.79 & 0.73 & 0.42 & 0.75 & 0.56 & 0.41 & 0.71 & 0.001 & 0.49 & 0.45 & 0.14 \\
\hline $\begin{array}{l}\text { MACCity/ } \\
\text { SEAC4RS }\end{array}$ & 0.70 & 0.78 & 0.73 & 0.37 & 0.76 & 0.52 & 0.48 & 0.78 & 0.02 & 0.54 & 0.45 & 0.08 \\
\hline
\end{tabular}

Table 6. Monthly-average biases of daytime (00:00, 06:00, 12:00 UTC) $\mathrm{O}_{3}$.

\begin{tabular}{|c|c|c|c|c|c|c|c|c|c|c|c|c|}
\hline \multirow[t]{2}{*}{$\begin{array}{l}\text { Emission } \\
\text { Inventories }\end{array}$} & \multicolumn{2}{|c|}{$\mathrm{CM}$} & \multicolumn{2}{|c|}{ KK } & \multicolumn{2}{|c|}{ SRB } & \multicolumn{2}{|c|}{ NTB } & \multicolumn{2}{|c|}{ CBR } & \multicolumn{2}{|c|}{ SRT } \\
\hline & Mar & Dec & Mar & Dec & Mar & Dec & Mar & Dec & Mar & Dec & Mar & Dec \\
\hline RETRO & 36.48 & 8.28 & 23.83 & 19.36 & 7.77 & 13.58 & 12.15 & 3.07 & 17.82 & 6.96 & 9.52 & 31.29 \\
\hline INTEX-B & 37.76 & 4.05 & 32.62 & 18.26 & 15.31 & 12.42 & 18.54 & 2.67 & 23.64 & 5.58 & 14.57 & 29.56 \\
\hline MACCity & 39.67 & 6.19 & 30.24 & 15.68 & 14.62 & 8.69 & 18.53 & -1.34 & 24.88 & 3.04 & 15.76 & 30.36 \\
\hline SEAC4RS & 38.53 & 3.75 & 31.45 & 20.14 & 17.29 & 13.98 & 27.90 & 4.61 & 24.38 & 6.33 & 11.26 & 29.15 \\
\hline $\begin{array}{l}\text { MACCity/ } \\
\text { SEAC4RS }\end{array}$ & 39.72 & 5.31 & 32.45 & 19.92 & 16.59 & 13.37 & 18.19 & -0.25 & 24.95 & 5.52 & 15.38 & 32.22 \\
\hline
\end{tabular}

This difference could be because the SEAC4RS emissions inventory lacks ship emissions. When the SEAC4RS emissions are combined with MACCity emissions, the $\mathrm{O}_{3}$ mixing ratios are more similar to the other simulations.

\subsection{4 $\mathrm{NO}_{2}$ evaluation}

The spatial distribution of the WRF-Chem and OMI tropospheric column $\mathrm{NO}_{2}$ are shown in Figs. 14 and 15 for March and December, respectively. In general, the WRF-Chem simulation is able to capture the $\mathrm{NO}_{2}$ pattern well over land in March with high $\mathrm{NO}_{2}$ columns over China, Burma, Vietnam, Laos, and Thailand and low values over the southern and southeast region of the model domain. The WRFChem $\mathrm{NO}_{2}$ column is generally less than the $\mathrm{OMI} \mathrm{NO}_{2}$ column. In March, the $\mathrm{OMI} \mathrm{NO}_{2}$ column values over land are $>2 \times 10^{15}$ molecules $\mathrm{cm}^{-2}$ with peak values of $\sim 5 \times 10^{15}$ molecules $\mathrm{cm}^{-2}$ over the Pearl River delta, while WRFChem predicts $1 \times 10^{15}$ molecules $\mathrm{NO}_{2} \mathrm{~cm}^{-2}$ or more. The WRF-Chem peaks of $\sim 5 \times 10^{15}$ occur in northern Thailand and Burma and not over the Pearl River delta. On the other hand, the WRF-Chem model underpredicts $\mathrm{NO}_{2}$ column in the southeastern region of the model domain. For March, the WRF-Chem $\mathrm{NO}_{2}$ column mostly reflects the biomass-burning emissions pattern (Fig. 3), while for December WRF-Chem is more similar to the anthropogenic emissions (Fig. 4). The OMI $\mathrm{NO}_{2}$ column does not show the high $\mathrm{NO}_{2}$ over northern Thailand and Burma where the model has high biomass-burning emissions in March. To ex- plain this difference, WRF-Chem fire emissions could be too high, or OMI may miss the high $\mathrm{NO}_{2}$ because of clouds interfering with the instrument's view. In situ measurements would allow us to evaluate better the performance of the model.

The largest variation among the model simulations is in the region near Indonesia and is a result of both low $\mathrm{NO}_{2}$ mixing ratios from the MOZART boundary conditions and different estimates for shipping emissions among the different inventories (Table 2, Figs. 3 and 4). Both the RETRO ship emissions, which are 75-80\% smaller than INTEX-B and MACCity ship emissions, and the SEAC4RS only simulation, which does not have ship emissions, contribute to the variation. When the MACCity ship emissions are combined with the SEAC4RS emissions (MACCity-SEAC4RS), the agreement with $\mathrm{OMI} \mathrm{NO}_{2}$ column is much better than the SEAC4RS only simulation. For example, the MACCitySEAC4RS simulation agrees better with $\mathrm{OMI} \mathrm{NO}_{2}$ column than the SEAC4RS only simulation. The $\mathrm{NO}_{2}$ column model-observation comparison for December (Fig. 15) shows that WRF-Chem slightly underpredicts the $\mathrm{NO}_{2}$ column, especially over the mainland. All five simulations predict relatively low $\mathrm{NO}_{2}$ column over Burma with values of $\sim 1 \times 10^{14}$ molecules $\mathrm{cm}^{-2}$ while $\mathrm{OMI} \mathrm{NO}_{2}$ column reports values of $5-10 \times 10^{14}$ molecules $\mathrm{cm}^{-2}$. Figure 4 shows that $\mathrm{NO}$ emissions in Burma are lower than the surrounding regions. The comparison to satellite data suggests that perhaps these emissions are too low. 


\section{Discussion}

There are several aspects of the simulations that contribute to the underprediction of $\mathrm{CO}$ at the surface and the overprediction of $\mathrm{O}_{3}$ at the surface. One is that the model simulation is for 2008 while the emission inventories are appropriate for other years (RETRO for 2000, INTEX-B for 2006, MACCity for 2010, and SEAC4RS for 2012). While the grid spacing of $36 \mathrm{~km}$ is better than global chemistry transport models, it is likely that small-scale features, e.g., urban regions and orography are not adequately represented in this simulation. For example, Chiang Mai is in a mountain valley where pollutants can easily accumulate. Another possible error could arise from the fire emissions. One issue with coarse resolution modeling of biomass-burning emissions is that multiple fires in one model grid cell are aggregated into a single, bigger fire area. This aggregated information is used by the plumerise model in WRF-Chem, which may erroneously apply too much thermal buoyancy associated with the fires, resulting in emissions placed too high above the ground. For example, WRF-Chem results without the plumerise feature of biomass-burning emissions, as illustrated by the March monthly averaged $\mathrm{CO}$ vertical profiles at Yangon, Burma (Fig. 16), show that injection into the lowest model level gives vertical profiles more consistent with MOZART results, which injects fire emissions into the lowest model level. Thus, in the simulations with the plumerise feature, $\mathrm{O}_{3}$ precursor species (NMVOCs and $\mathrm{NO}_{\mathrm{x}}$ ) may be placed in an environment where $\mathrm{O}_{3}$ production is more productive than if the precursors were placed near the surface. While these results indicate a substantial difference in $\mathrm{CO}$ mixing ratios in the lowest $500 \mathrm{hPa}$ of the atmosphere, observations of $\mathrm{CO}$ vertical profiles are needed to help evaluate the model predictions. In addition, trash burning emissions are not included in this study, yet have been shown to have a significant contribution to the air quality (Hodzic et al., 2012). In reality, Southeast Asia has complex emission sources that not only include biomass burning and anthropogenic activities, but also biofuel and trash burning. To improve simulations of $\mathrm{CO}$ in the future, these other emissions should be included.

Another possible cause of the $\mathrm{CO}$ underprediction and $\mathrm{O}_{3}$ overprediction at the surface is that the anthropogenic emissions are too low. Global estimates of CO sources (Kopacz et al., 2010) based on satellite, aircraft, and surface observations suggest that $\mathrm{CO}$ emissions over Southeast Asia are underestimated by nearly a factor of 2 . For the INTEX-B emissions, Zhang et al. (2009) reported an uncertainty of $185 \%$ and $37 \%$ for $\mathrm{CO}$ and $\mathrm{NO}$ emissions, respectively. We conducted sensitivity simulations with higher $\mathrm{CO}$ emissions by a factor of 2 and higher NO emissions by $40 \%$. Additional sensitivity simulations were performed with only $\mathrm{CO}$ emissions greater by a factor of 2 (NO emissions remained the same as the original inventory). The sensitivity simulations were performed for March when biomass burning is a major contribution to the results. The results were compared to the six ground sites shown in Fig. 5g. The higher emissions improve agreement for both $\mathrm{O}_{3}$ and $\mathrm{CO}$ concentrations at the six monitoring sites. For example, the $\mathrm{O}_{3}$ prediction from the increased emission simulations, on average, improved the correlation term by $\sim 18 \%$ and reduced the bias from $24 \mathrm{ppbv}$ to 8 ppbv. The high emissions simulations decreased, on average, the correlation for $\mathrm{CO}$ surface mixing ratios by 23$34 \%$, but reduced the average bias from $250-264$ ppbv to 184-224 ppbv. Interestingly, the high emissions simulations produced too much $\mathrm{CO}$ at Chiang Mai by over 400 ppbv, yet the $\mathrm{O}_{3}$ bias at Chiang Mai was reduced to 2-4 ppbv (from 38 to $40 \mathrm{ppbv}$ ). This suggests that either the $\mathrm{CO}$ emissions from biomass burning are too high, or co-emitted VOCs should have higher emissions. The Saraburi site, downwind of Bangkok, went from too little $\mathrm{CO}$ (bias $=-150 \mathrm{ppbv}$ for INTEX-B) to too much CO (bias $=173 \mathrm{ppbv}$ for INTEX$\mathrm{B}$ high emissions simulations) with only a 2 ppbv decrease in bias of $\mathrm{O}_{3}$. $\mathrm{CO}$ at Surat Thani changed very little, because Surat Thani is located away from urban and biomassburning regions. At the same time, Khon Kaen, Nonthaburi, and Chonburi all have a better correspondence to observations as shown by the decreased bias. However, WRF-Chem still underpredicts $\mathrm{CO}$ at these sites. The higher emissions slightly improved the prediction of $\mathrm{NO}_{2}$ mixing ratios increasing the correlation coefficient by $18 \%$ but not changing the bias on average. By comparing the simulation with increased $\mathrm{CO}$ and $\mathrm{NO}$ emissions to the simulation with only increase $\mathrm{CO}$ emissions, the results for $\mathrm{O}_{3}$ and $\mathrm{CO}$ are very similar indicating that increased $\mathrm{CO}$ emissions caused the decrease in $\mathrm{O}_{3}$ concentrations.

Our WRF-Chem simulations did not include heterogeneous chemistry, which can affect $\mathrm{OH}$ concentrations (Mao et al., 2013) and therefore CO oxidation. Kumar et al. (2014) also found decreased $\mathrm{OH}$ and $\mathrm{O}_{3}$ mixing ratios when heterogeneous chemistry was included for a simulation of a dust event over India. For this high dust-loading example of the effect of heterogeneous chemistry, $\mathrm{O}_{3}$ decreased by 10 20 ppbv.

The underprediction of $\mathrm{NO}_{2}$ in all the WRF-Chem simulations suggests that the anthropogenic $\mathrm{NO}_{\mathrm{x}}$ emissions are underestimated over the Southeast Asia. These errors in anthropogenic emission estimates are likely due to uncertainties in including all the $\mathrm{CO}$ or $\mathrm{NO}_{\mathrm{x}}$ sources from the different emission sectors and estimating the emission factors from the different sources. The variation in NO shipping emissions, as seen by the comparison of the simulation using only the SEAC4RS emissions without shipping emissions with the simulation using MACCity-SEAC4RS emissions, does produce substantial variation among model predictions of $\mathrm{NO}_{2}$ (Fig. 14) and $\mathrm{O}_{3}$ (Fig. 13). Therefore, it is important to include the shipping sector as part of the emissions inventory.

This paper did not include the REAS emissions inventory. For Southeast Asia the REAS v2.1 CO emissions are similar to the TRACE-P (Streets et al., 2003) and INTEX-B (Zhang 
Table 7. Monthly-average surface ozone and carbon monoxide mixing ratios at land-based grid points in Southeast Asia.

\begin{tabular}{lcclcc}
\hline \multirow{2}{*}{ Emission Inventories } & \multicolumn{2}{c}{$\mathrm{CO}(\mathrm{ppb})$} & & \multicolumn{2}{c}{$\mathrm{O}_{3}(\mathrm{ppb})$} \\
\cline { 2 - 3 } \cline { 6 - 7 } & Mar & Dec & & Mar & Dec \\
\hline RETRO & 571 & 596 & & 146 & 122 \\
INTEX-B & 575 & 497 & & 156 & 119 \\
MACCity & 574 & 495 & & 160 & 122 \\
SEAC4RS & 574 & 494 & & 159 & 122 \\
MACCity/SEAC4RS & 575 & 495 & & 154 & 115 \\
\hline
\end{tabular}

et al., 2009) emission inventories for years 2000 and 2006, respectively. The REAS v2.1 $\mathrm{NO}_{\mathrm{x}}$ emissions are also similar to the TRACE-P emissions inventory for 2000, but are lower than the INTEX-B inventory for year 2006 (Kurakawa et al., 2013). We would then expect the REAS v2.1 inventory to produce similar results for $\mathrm{CO}$ surface mixing ratios as the INTEX-B emissions inventory did, but have lower $\mathrm{NO}_{\mathrm{x}}$ mixing ratios, if the year 2006 REAS inventory is used. The 2008 REAS v2.1 emissions are 10-20\% greater than their 2006 emissions. These increased emissions would likely give results for $\mathrm{CO}$ and $\mathrm{O}_{3}$ surface mixing ratios that are $<10 \%$ greater than the mixing ratios simulated in this study. To confirm this, additional WRF-Chem simulations should be done with the REAS emissions inventory.

The goal of this paper is to examine the differences in predicted $\mathrm{CO}$ and $\mathrm{O}_{3}$ mixing ratios at the surface when different anthropogenic emission inventories are used. Table 6 lists monthly average $\mathrm{O}_{3}$ and $\mathrm{CO}$ mixing ratios on land for March and December for all of simulation cases. During the biomass-burning season (March), the average $\mathrm{CO}$ differs by less than 5 ppbv ( $<1 \%$ difference) among the different emission inventories, while average $\mathrm{O}_{3}$ ranges from 146 to $160 \mathrm{ppbv}$ ( $9 \%$ difference) among the different emission inventories. In December when anthropogenic emissions are greater than biomass-burning emissions, the differences in average $\mathrm{CO}$ and $\mathrm{O}_{3}$ among the different emission inventories is very small ( $2 \mathrm{ppbv}$ for $\mathrm{CO}$ and $7 \mathrm{ppbv}$ for $\mathrm{O}_{3}$ ). These small variations, which are also seen in the mean bias calculations for the ground-based sites (Tables 3 and 5), suggest that the choice of the emission inventory does not have a substantial effect on $\mathrm{CO}$ and $\mathrm{O}_{3}$ surface concentrations, despite the different emission inventories having a $\sim 30 \%$ variation for $\mathrm{CO}$ and $10 \%$ variation for $\mathrm{NO}$ emissions.

By comparing the March average mixing ratios to the December average mixing ratios (Table 7), the importance of biomass-burning emissions on $\mathrm{O}_{3}$ and $\mathrm{CO}$ variability is revealed. In March, CO is $16 \%$ greater than CO in December for all simulations except that with RETRO emissions. The average $\mathrm{O}_{3}$ in March is $\sim 30 \%$ greater than average $\mathrm{O}_{3}$ in December. These differences are much greater than those induced by the anthropogenic emissions in Southeast Asia. Thus, biomass-burning emissions produce more variability in WRF-Chem simulation results than the different anthropogenic emission inventories.

\section{Conclusions}

This study presents WRF-Chem results to show the variability of emissions on surface $\mathrm{O}_{3}$ and $\mathrm{CO}$ mixing ratios in Southeast Asia. The predicted meteorological fields are evaluated with reanalysis output (MERRA), satellite data (TRMM) and ground-based observations (GPCC) for $2 \mathrm{~m}$ temperature, wind, and precipitation. Surface $\mathrm{CO}$ and $\mathrm{O}_{3}$ mixing ratios are compared to ground-based monitoring observations in Thailand. Surface CO is also compared to MOPITT satellite data. $\mathrm{O}_{3}$ vertical profiles are compared with SHADOZ ozonesonde data, and the $\mathrm{NO}_{2}$ tropospheric column is evaluated with OMI satellite data.

In general, the temperature and winds showed good agreement with MERRA output, although there was a slight underestimate of temperature and slight overestimate of wind speed. Precipitation was reasonably predicted for regions north of $10^{\circ} \mathrm{N}$ in comparison to TRMM and GPCC data, but was overestimated near the equator. By using a grid spacing of $36 \mathrm{~km}$, the precipitation was generated mostly by the cumulus parameterization in the model resulting in a less reliable prediction of rain and convective mass fluxes between the boundary layer and mid- to upper troposphere. Surface $\mathrm{O}_{3}$ mixing ratios were generally higher than observations and surface $\mathrm{CO}$ mixing ratios were lower than observations. Although the emission inventories were for years other than that simulated here, the differences in surface $\mathrm{O}_{3}$ and $\mathrm{CO}$ mixing ratios among the simulations with different inventories were small. Thus, the model biases are likely not the result of the emission inventory trends used here, but more likely caused by the omission of sources such as trash burning and biofuel use and uncertainties not fully captured in the current emission inventories. Sensitivity simulations with doubled $\mathrm{CO}$ emissions showed that the model-observation agreement improved substantially for $\mathrm{CO}$ and $\mathrm{O}_{3}$. Thus, further study of the role of different emission sectors on $\mathrm{CO}$ and $\mathrm{O}_{3}$ can help elucidate where the major weaknesses are in the emission inventories. In addition, analysis of the contribution of $\mathrm{CO}, \mathrm{NO}_{\mathrm{x}}, \mathrm{O}_{3}$, and VOCs from outside the Southeast Asia region on the region's air quality should be compared with the contribution of the local emissions.

Simulations using different anthropogenic emissions created only a slight variability of $\mathrm{O}_{3}$ and $\mathrm{CO}$ mixing ratios, while biomass-burning emissions added more variability. The different anthropogenic emissions have up to $30 \%$ difference in $\mathrm{CO}$ emissions but only a small change of $\mathrm{O}_{3}$ and CO mixing ratios of $\sim 4.5 \%$ and $\sim 8 \%$, respectively, among the simulations. A statistical analysis showed that the different model results are statistically different for $\mathrm{CO}$ mixing ratios at the Thai monitoring sites, and none are statistically different for $\mathrm{O}_{3}$ except in southern Thailand during 
March. By comparing March (when biomass burning is at its peak) surface mixing ratios to December values, it is found that biomass-burning emissions substantially increase both $\mathrm{O}_{3}$ and $\mathrm{CO}$ mixing ratios by $\sim 30 \%$ and $\sim 16 \%$.

Southeast Asia is a region with complex terrain and emission sources at small scales. Thus, one important test to improve the regional-scale simulations of air quality in Southeast Asia would be to use model grid spacing of the order of $10 \mathrm{~km}$ or less. A higher grid resolution should also reduce errors in the injection height of biomass-burning emissions. However, a high-resolution simulation needs emission inventories at equally high resolution. Inclusion of other types of emissions, e.g., trash emissions, in the current inventories could also improve the representation of the atmospheric chemistry in Southeast Asia. Lastly, particulate matter (aerosols) was not addressed in this study. Not only should their contribution to air quality be evaluated, but their impact on gas-phase photochemistry should be addressed.

Acknowledgements. The authors would like to thank the National Center for Atmospheric Research (NCAR) Advanced Study Program (ASP) for the scholarship to visit the Atmospheric Chemistry Division (ACD), the Center for Environmental Health, Toxicology and Management of Chemical, Chiang Mai University, Faculty of Science, Chiang Mai, Thailand for Ph.D. scholarship, and the Graduate School Chiang Mai University for partial support. The study was partially supported by NSF CHEM award 1049058. We are thankful for the Thai Pollution Control Department (PCD) providing their $\mathrm{O}_{3}$ and $\mathrm{CO}$ observation data. We also acknowledge the Global Modeling and Assimilation Office (GMAO) and the GES DISC for the dissemination of MERRA, the NASA Goddard Space Flight Center for providing SHADOZ data, and the NASA Langley Research Center Atmospheric Science Data Center for providing MOPITT data. Analyses and visualizations used in this paper were produced with the Giovanni online data system, developed and maintained by the NASA GES DISC. We acknowledge Gabriele Pfister and Sachin Ghude for their assistance with WRF-Chem simulations. The comments from the anonymous reviewers, Christine Wiedinmyer and Rajesh Kumar are greatly appreciated. NCAR is operated by the University Corporation for Atmospheric Research (UCAR) under sponsorship of the National Science Foundation.

Edited by: H. Su

\section{References}

Adhikary, B., Carmichael, G. R., Tang, Y., Leung, L. R., Qian, Y., Schauer, J. J., Stone, E. A., Ramanathan, V., and Ramana, M. V.: Characterization of South Asian Aerosols during the ABC-Post Monsoon Experiment (ABC-APMEX): a regional-scale modeling analysis, J. Geophys. Res., 112, D22S22, doi:10.1029/2006JD008143, 2007.
Akimoto, $\mathrm{H}$. and Narita, $\mathrm{H}$.: Distribution of $\mathrm{SO}_{2}, \mathrm{NO}_{\mathrm{x}}$, and $\mathrm{CO}_{2}$ emissions from fuel combustion and industrial activities in Asia with $1^{\circ} \times 1^{\circ}$ resolution, Atmos. Environ., 28, 213-225, 1994.

Amnuaylojaroen, T. and Kreasuwun, J.: Investigation of fine and coarse particulate matter from burning areas in Chiang Mai, Thailand using the WRF/CALPUFF, Chiang Mai, J. Sci., 39, 116, 2012.

Boersma, K. F., Jacob, D. J., Eskes, H. J., Pinder, R. W., Wand, J., and Vander A, R. J.: Intercomparison of SCIAMACHY and OMI tropospheric $\mathrm{NO}_{2}$ columns: observing the diurnal evolution of chemistry and emissions from space, J. Geophys. Res., 113, D16S26, doi:10.1029/2007JD008816, 2008.

Boersma, K. F., Jacob, D. J., Trainic, M., Rudich, Y., DeSmedt, I., Dirksen, R., and Eskes, H. J.: Validation of urban $\mathrm{NO}_{2}$ concentrations and their diurnal and seasonal variations observed from the SCIAMACHY and OMI sensors using in situ surface measurements in Israeli cities, Atmos. Chem. Phys., 9, 3867-3879, doi:10.5194/acp-9-3867-2009, 2009.

Bucsela, E. J., Celarier, E. A., Wening, M. O., Gleason, J. F., Veefkind, J. P., Boersma, K. F., and Brinksma, E. J.: Algorithm for $\mathrm{NO}_{2}$ vertical column retrieval from the Ozone Monitoring Instrument, IEEE T. Geosci. Remote, 44, 1245-1258, 2006.

Chen, F. and Dudhia, J.: Coupling an advanced landsurface/hydrology model with the Penn State/NCAR MM5 modeling system, Part 1: Model description and implementation, Mon. Weather. Rev., 129, 569-585, 2001.

Chin, M., Rood, R. B., Lin, S.-J., Muller, J. F., and Thompson, A. M.: Atmospheric sulfur cycle in the global model GOCART: model description and global properties, J. Geophys. Res., 105, 24671-24687, 2000.

Chou, M.-D. and Suarez, M. J.: An efficient thermal infrared radiation parameterization for use in general circulation models, NASA Tech. Memo. 104606, 3, 85 pp., NASA/GSFC, Greenbelt, MD, 1994.

Deeter, M. N.: MOPITT (Measurement of Pollution in the Troposphere) Version6 Product User'sGuide, available at: http://www2.acd.ucar.edu/sites/default/files/mopitt/v6_users_ guide_201309.pdf (last access: 12 September 2014), 2013.

Deeter, M. N., Worden, H. M., Gille, J. C., Edwards, D. P., Mao, D., and Drummond, J. R.: MOPITT multispectral CO retrievals: Origins and effects of geophysical radiance errors, J. Geophys. Res.,116, D15303, doi:10.1029/2011JD015703, 2011.

Deeter, M. N., Worden, H. M., Edwards, D. P., Gille, J. C., and Andrews, A. E.: Evaluation of MOPITT retrievals of lowertropospheric carbon monoxide over the United States, J. Geophys. Res., 117, D13306, doi:10.1029/2012JD017553, 2012.

Deeter, M. N., Martinez-Alonso, S., Edwards, D. P., Emmons, L. K., Gille, J. C., Worden, H. M., Pittman, J. V., Daube, B. C., and Wofsy, S. C.: Validation of MOPITT version 5 thermalinfrared, near-infrared, and multispectral carbon monoxide profile retrievals for 2000-2011, J. Geophys. Res., 118, 6710-6725, doi:10.1002/jgrd.50272, 2013.

Deng, X., Tie, X., and Zhou, X.: Effects of Southeast Asia biomass burning on aerosols and ozone concentrations over the Pearl River Delta (PRD) region, Atmos. Environ., 42, 8493-8501, doi:10.1016/j.atmosenv.2008.08.013, 2008.

Emmons, L. K., Deeter, M. N., Gille, J. C., Edwards, D. P., Attie, J.-L., Warner, J., Ziskin, D., Francis, G., Khattatov, B., Yudin, V., Lamarque, J. -F., Ho, S. -P., Mao, D., Chen, J. S., 
Drummond, J., Novelli, P., Sachse, G., Coffey, M.., Hannigan, J. W., Gerbig, C., Kawakami, S., Kondo, Y., Takegawa, N., Schlager, H., Baehr, J., and Ziereis, H.: Validation of Measurements of Pollution in the Troposphere (MOPITT) CO retrievals with aircraft in situ profiles, J. Geophys. Res., 109, D03309, doi:10.1029/2003JD004101, 2004.

Emmons, L. K., Pfister, G. G., Edwards, D. P., Gille, J. C., Sachse, G., Blake, D., Wofsy, S., Gerbig, C., Matross, D., and Nedelec, P.: Measurements of Pollution in the Troposphere (MOPITT) validation exercises during summer 2004 field campaigns over North America, J. Geophys. Res., 112, D12S02, doi:10.1029/2006JD007833, 2007.

Emmons, L. K., Edwards, D. P., Deeter, M. N., Gille, J. C., Campos, T., Nédélec, P., Novelli, P., and Sachse, G.: Measurements of Pollution In The Troposphere (MOPITT) validation through 2006, Atmos. Chem. Phys., 9, 1795-1803, doi:10.5194/acp-91795-2009, 2009.

Emmons, L. K., Walters, S., Hess, P. G., Lamarque, J.-F., Pfister, G. G., Fillmore, D., Granier, C., Guenther, A., Kinnison, D., Laepple, t., Orlando, J., Tie, X., Tyndall, G., Wiedinmyer, C., Baughcum, S. L., and Kloser, S.: Description and evaluation of the Model for Ozone and Related chemical Tracers, version 4 (MOZART4), Geosci. Model. Dev., 3, 43-67, 2010.

Fast, J. D., Gustafson Jr, W. I., Easter, R. C., Zaveri, R. A., Barnard, J. C., Chapman, E. G., and Grell, G. A.: Evolution of ozone, particulates, and aerosol direct forcing in an urban area using a new fully-coupled meteorology, chemistry, and aerosol model, J. Geophys. Res., 111, D21305, doi:10.1029/2005JD006721, 2006.

Geng, F., Tie, X., Guenther, A., Li, G., Cao, J., and Harley, P.: Effect of isoprene emissions from major forests on ozone formation in the city of Shanghai, China, Atmos. Chem. Phys., 11, 1044910459, doi:10.5194/acp-11-10449-2011, 2011.

Ghude, S. D., Pfister, G. G., Jena, C. K., Van der A, R. J., Emmons, L. K., and Kumar, R.: Satellite constraints of nitrogen oxide $\left(\mathrm{NO}_{\mathrm{x}}\right)$ emissions from India based on OMI observations and WRF-Chem simulations, Geophys. Res. Lett., 40, 1-6, doi:10.1029/2012GL053926, 2013.

Granier, C., Bessagnet, B., Bond, T., Angiola, A. D., Van Der Gon, H. D.., Frost, G. J., Heil, A., Kaiser, J. W., Kinne, S., Klimont, Z., Kloster, S., Lamarque, J. -F., Liousse, C., Masui, T., Meleux, F., Mieville, A., Ohara, T., Raut, J.-C., Riahi, K., Schultz, M. G., Smith, S. J., Thompson, A., Aardenne, J. V., Vander Werf, G. R., and Van Vuuren, D. P.: Evolution of anthropogenic and biomass burning emission of air pollutants at global and regional scales during the 1980-2010 period, Clim. Change, 109, 163-190, 2011.

Grell, G. A. and Devenyi, D.: A generalized approach to parameterizing convection combining ensemble and data assimilation techniques, Geophys. Res. Lett., 29, 1693, doi:10.1029/2002GL015311, 2002.

Grell, G. A., Peckham, S. E., Schmitz, R., McKeen, S. A., Frost, G., Skamarock, W. C., and Eder, B.: Fully coupled "online" chemistry within the WRF model, Atmos. Environ., 29, 6957-6975, 2005.

Guenther, A., Karl, T., Harley, P., Wiedinmyer, C., Palmer, P. I., and Geron, C.: Estimates of global terrestrial isoprene emissions using MEGAN (Model of Emissions of Gases and Aerosols from
Nature), Atmos. Chem. Phys., 6, 3181-3210, doi:10.5194/acp-63181-2006, 2006.

Han, Z., Sakurai, T., Ueda, H., Matsuda, K., Hozumi, Y., Carmichael, G. R., Streets, D. G., Park, S. U., Fung, C., Chang, A., Kajino, M., Thongboonchoo, N., Engardt, M., Bennet, C., Hayami, H., Sartelet, K., Holloway, T., Wang, Z., and Amann, M.: Model intercomparison and evaluation of ozone and relevant species - MICS-Asia phase II study, Atmos. Environ., 42, 3491-3509, 2008.

Hodzic, A., Wiedinmyer, C., Salcedo, D., and Jimenez, J. L.: Impact of trash burning on air quality in Mexico City, Environ. Sci Technol., 46, 4950-4957, doi:10.1021/es203954r, 2012.

Hollingsworth, A., Engelen, R. J., Textor, C., Benedetti, A., Boucher, O., Chevallier, F., Dethof, A., Elbern, H., Eskes, H., Flemming, J., Granier, C., Morcrette, J. J., Rayner, P., Peuch, V.H., Rouil, L., Schultz, M., and Simmons, A. J.: Toward a monitoring and forecasting system for atmospheric composition: the GEMS project, B. Am. Meteorol. Soc., 89, 1147-1164, doi:10.1175/2008BAMS2355.1, 2008.

Huffman, G. J. and Bolvin, D. T.: TRMM and Other Data Precipitation Data Set Document, available at: ftp://precip.gsfc.nasa.gov/ pub/trmmdocs/3B42_3B43_doc.pdf (last access: 14 September 2014), 2012

Huffman, G. J., Adler, R. F., Arkin, P., Chang, A., Ferraro, R., Gruber, A., Janowiak, J., McNab, A., Rudolph, B., and Schneide, U.: The Global Precipitation Climatology Project (GPCP) combined precipitation dataset, B. Am. Meteorol. Soc., 78, 5-20, 1997.

Janjic, Z. I.: Nonsingular Implementation of the Mellor-Yamada Level 2.5 Scheme in the NCEP Meso model, National Oceanic and Atmospheric Administration Science Center, Camp Springs, MD, NCEP Office Note, No. 437, 61, 2002.

Koo, M.-S. and Hong, S.-Y.: Diurnal variations of simulated precipitation over East Asia in two regional climate models, J. Geophys. Res., 115, D05105, doi:10.1029/2009JD012574, 2010.

Kopacz, M., Jacob, D. J., Fisher, J. A., Logan, J. A., Zhang, L., Megretskaia, I. A., Yantosca, R. M., Singh, K., Henze, D. K., Burrows, J. P., Buchwitz, M., Khlystova, I., McMillan, W. W., Gille, J. C., Edwards, D. P., Eldering, A., Thouret, V., and Nedelec, P.: Global estimates of CO sources with high resolution by adjoint inversion of multiple satellite datasets (MOPITT, AIRS, SCIAMACHY, TES), Atmos. Chem. Phys., 10, 855-876, doi:10.5194/acp-10-855-2010, 2010.

Kramer, L. J., Leigh, R. J., Remedios, J. J., and Monks, P. S.: Comparison of OMI and ground-based in situ and MAX-DOAS measurements of tropospheric nitrogen dioxide in an urban area, J. Geophys. Res., 113, D16S39, doi:10.1029/2007jd009168, 2008.

Kruskal, W. H. and Wallis, W. A.: Use of ranks in onecriterion variance analysis, J. Am. Statist. Assoc., 47, 583-621, doi:10.1080/01621459.1952.10483441, 1952.

Kumar, R., Naja, M., Pfister, G. G., Barth, M. C., and Brasseur, G. P.: Source attribution of carbon monoxide in India and surrounding regions during wintertime, J. Geophys. Res., 118, 1981-1995, doi:10.1002/jgrd.50134, 2013.

Kumar, R., Barth, M. C., Madronich, S., Naja, M., Carmichael, G. R., Pfister, G. G., Knote, C., Brasseur, G. P., Ojha, N., and Sarangi, T.: Effects of dust aerosols on tropospheric chemistry during a typical pre-monsoon season dust storm in northern India, Atmos. Chem. Phys., 14, 6813-6834, doi:10.5194/acp-146813-2014, 2014. 
Kurokawa, J., Ohara, T., Morikawa, T., Hanayama, S., JanssensMaenhout, G., Fukui, T., Kawashima, K., and Akimoto, H.: Emissions of air pollutants and greenhouse gases over Asian regions during 2000-2008: Regional Emission inventory in ASia (REAS) version 2, Atmos. Chem. Phys., 13, 11019-11058, doi:10.5194/acp-13-11019-2013, 2013.

Lamarque, J.-F., Bond, T. C., Eyring, V., Granier, C., Heil, A., Klimont, Z., Lee, D., Liousse, C., Mieville, A., Owen, B., Schultz, M. G., Shindell, D., Smith, S. J., Stehfest, E., Van Aardenne, J., Cooper, O. R., Kainuma, M., Mahowald, N., McConnell, J. R., Naik, V., Riahi, K., and van Vuuren, D. P.: Historical (1850-2000) gridded anthropogenic and biomass burning emissions of reactive gases and aerosols: methodology and application, Atmos. Chem. Phys., 10, 7017-7039, doi:10.5194/acp10-7017-2010, 2010.

Liu, C.-H., Yeh, M. T., and Paul, S.: Effect of anthropogenic emissions in East Asia on regional ozone levels during spring cold continental outbreaks near Taiwan: a case study, Environ. Modell. Softw., 23, 579-591, 2008.

Lu, Z. and Streets, D. G.: The Southeast Asia Composition, Cloud, Climate Coupling Regional Study Emission Inventory, available at: http://bio.cgrer.uiowa.edu/SEAC4RS/emission.html (last access: 26 March 2014), 2012.

Mao, J., Fan, S., Jacob, D. J., and Travis, K. R.: Radical loss in the atmosphere from $\mathrm{Cu}-\mathrm{Fe}$ redox coupling in aerosols, Atmos. Chem. Phys., 13, 509-519, doi:10.5194/acp-13-509-2013, 2013.

Mlawer, E. J., Taubman, S. J., Brown, P. D., Iacono, M. J., and Clough, S. A.: Radiative transfer for inhomogeneous atmosphere: RRTM, a validated correlated-k model for the longwave, J. Geophys. Res., 102, 16663-16682, 1997.

Neu, J. L. and Prather, M. J.: Toward a more physical representation of precipitation scavenging in global chemistry models: cloud overlap and ice physics and their impact on tropospheric ozone, Atmos. Chem. Phys., 12, 3289-3310, doi:10.5194/acp-12-32892012, 2012.

Ohara, T., Akimoto, H., Kurokawa, J., Horii, N., Yamaji, K., Yan, X., and Hayasaka, T.: An Asian emission inventory of anthropogenic emission sources for the period 1980-2020, Atmos. Chem. Phys., 7, 4419-4444, doi:10.5194/acp-7-4419-2007, 2007.

Olivier, J. G. J., Van Aardenne, J. A., Dentener, F., Ganzeveld, L., and Peters, J. A. H. W.: Recent trends in global greenhouse gas emissions: regional trends and spatial distribution of key sources, Environ. Sci., 2, 81-99, doi:10.1080/15693430500400345, 2005.

Rienecker, M. M., Suarez, M. J., Gelaro, R., Todling, R., Bacmeister, J., Liu, E., Bosilovich, M. G., Schubert, S. D., Takacs, L., Kim, G.-K., Bloom, S., Chen, J., Collins, D., Conaty, A., Da Silva, A., Gu, W., Joiner, J., Koster, R. D., Lucchesi, R., Molod, A., Owens, T., Pawson, S., Pegion, P., Redder, C. R., Reichle, R., Robertson, F. R., Ruddick, A. G., Sienkiewicz, M., and Woollen, J.: MERRA - NASA's Modern-Era Retrospective Analysis for Research and Applications, J. Climate, 24, 36243648, doi:10.1175/JCLI-D-11-00015.1, 2011.

Rudolf, B. and Schneider, U.: Calculation of Gridded Precipitation Data for the Global Land-Surface using in-situ Gauge Observations, Proceedings of the 2nd Workshop of the International Precipitation Working Group IPWG, Monterey, 25-28 October 2004, EUMETSAT, 231-247, 2005.
Sandu, A. and Sander, R.: Technical note: Simulating chemical systems in Fortran90 and Matlab with the Kinetic PreProcessor KPP-2.1, Atmos. Chem. Phys., 6, 187-195, doi:10.5194/acp-6187-2006, 2006.

Schaap. M., Roemer, M., Sauter, F., Boersen, G., Timmermans, R., Builtjes, P. J. H., and Vermeulen, A. T. LOTOS-EUROS: Documentation, TNO-report: B\&O-A R 2005/297, available at: http://www.lotos-euros.nl/doc/ LOTOS-EUROS-v11-documentation.pdf (last access: 12 September 2014), 2005.

Schneider, U., Becker, A., and Meyer-Christofer, A.: Global Precipitation Analysis Products of the GPCC, available at: ftp://ftp-anon.dwd.de/pub/data/gpcc/PDF/GPCC_intro_ products_2008.pdf (last access: 12 September 2014), 2011a.

Schneider, U., Becker, A., Finger, P., Meyer-Christoffer, A., Rudolf, B., Ziese, M.: GPCC Full Data Reanalysis Version 6.0 at 1.0deg: Monthly Land-Surface Precipitation from Rain-Gauges built on GTS-based and Historic Data, doi:10.5676/DWD_GPCC/FD_M_V6_100, 2011b.

Schultz, M., Rast, S., van het Bolscher, M., Pulles, T., Pereira, J., Spessa, A., Dalsøren, S., van Nojie, T., and Szopa, S.: REanalysis of the TROpospheric chemical composition over the past 40 years, a long-term global modeling study of tropospheric chemistry funded under the 5th EU framework programme, Tech. rep., EU-Contract No. EVK2-CT-2002-00170, available at: http: //retro.enes.org/reports/D1-6_final.pdf (last access: 12 September 2014), 2007.

Skamarock, W. C., Klemp, J. B., Duhia, J., Gill, D. O., Barker, D. M., Duda, M. G., Huang, X.-Y., Wang, W., and Powers, J. G.: A Description of the Advanced Research WRF Version 3, NCAR Technical note, National Center for Atmospheric Research, Boulder, CO, USA, 2008.

Shepard, D.: A two-dimensional interpolation function for irregularly spaced data, in Proceedings of the 1968 23rd ACM National Conference, ACM, New York, NY, USA, 517-524, 1968.

Stauffer, D. R. and Seaman, N. L.: Use of four-dimensional data assimilation in a limited area mesoscale model, Part 1: Experiments with synoptic-scale data, Mon. Weather. Rev., 118, 1250-1277, 1990.

Streets, D. G., Bond, T. C., Carmichael, G. R., Fernandes, S. D., Fu, Q., He, D., Klimont, Z., Nelson, S. M., Tsai, N. Y., Wang, M. Q., Woo, J.-H., and Yarber, K. F.: An inventory of gaseous and primary aerosol emissions in Asia in the year 2000, J. Geophys. Res., 108, 8809, doi:10.1029/2002JD003093, 2003.

Tanimoto, H., Ohara, T., and Uno, I.: Asian anthropogenic emissions and decadal trends in springtime tropospheric ozone over Japan: 1998-2007, Geophys. Res. Lett., 36, L23802, doi:10.1029/2009GL041382, 2009.

Thompson, A. M., Miller, S. K., Tilmes, S., Kollonige, D. W., Witte, J. C., Oltmans, S. J., Johnson, B. J., Fujiwara, M., Schmidlin, F. J., Coetzee, G. J. R., Komala, N., Maata, M., Mohamad, M., Nguyo, J., Mutai, C., Ogino, S. -Y., Da Silva, R. F., Paes Leme, N. M., Posny, F., Scheele, R., Selkirk, H. B., Shiotani, M., Stubi, R., Levrat, G., Calpini, B., Thouret, V., Tsuruta, H., Canossa, J. V., Vomel, H., Yonemura, S., Diaz, J. A., Tan Thanh, N. T., and Ha, T.: Southern Hemisphere Additional Ozonesondes (SHADOZ) ozone climatology (2005-2009): Tropospheric and tropical tropopause layer (TTL) profiles with comparisons 
to OMI-based ozone products, J. Geophys. Res., 117, D23301, doi:10.1029/2011JD016911, 2012.

Thompson, G., Rasmussen, R. M., and Manning, K.: Explicit forecasts of winter precipitation using an improved bulk microphysics scheme, Part 1: Description and sensitivity analysis, Mon. Weather. Rev., 132, 519-542, 2004.

Tie, X., Madronich, S., Walters, S., Zhang, R., Rasch, P., and Collins, W.: Effects of clouds on photolysis and oxidants in the troposphere, J. Geophys. Res., 108, 4642, doi:10.1029/2003JD003659, 2003.

Van Vuuren, D. P., Edmonds, J., Kainuma, M., Riahi, K., Thomson, A., Hibbard, K., Hurtt, G. C., Kram, T., Krey, V., and Lamarque, J.-F.: The representative concentration pathways: an overview, Climatic Change, 109, 5-31, 2011.

Wang, H., Skamarock, W. C., and Feingold, G.: Evaluation of scalar advection schemes in the advanced research WRF model using large-eddy simulations of aerosol-cloud interactions, Mon. Weather. Rev., 137, 2547-2558, 2009.

Wang, X., Carmichael, G. R., Chen, D., Tang, Y., and Wang, T.: Impacts of different emission sources on air quality during March 2001 in the Pearl River Delta (PRD) region, Atmos. Environ., 39, 5227-5241, doi:10.1016/j.atmosenv.2005.04.035, 2005.

Wang, Y., Zhang, Y., Hao, J., and Luo, M.: Seasonal and spatial variability of surface ozone over China: contributions from background and domestic pollution, Atmos. Chem. Phys., 11, 35113525, doi:10.5194/acp-11-3511-2011, 2011.

Wesley, M. L.: Parameterization of surface resistance to gaseous dry deposition in regional numerical models, Atmos. Environ., 16, 1293-1304, 1989.
Wiedinmyer, C., Akagi, S. K., Yokelson, R. J., Emmons, L. K., AlSaadi, J. A., Orlando, J. J., and Soja, A. J.: The Fire INventory from NCAR (FINN): a high resolution global model to estimate the emissions from open burning, Geosci. Model Dev., 4, 625641, doi:10.5194/gmd-4-625-2011, 2011.

Willmott, C. J., Rowe, C. M., Philpot, W. D.: Small scale climate maps: a sensitivity analysis of some common assumption associated with grid point interpolation and contouring, Am. Cartographer, 12, 5-16, 1985.

Worden, H. M., Deeter, M. N., Edwards, D. P., Gille, J. C., Drummond, J. R., and Nédélec, P.: Observations of near-surface carbon monoxide from space using MOPITT multispectral retrievals, J. Geophys., Res., 115, D18314, doi:10.1029/2010JD014242, 2010.

Zhang, Q., Streets, D. G., Carmichael, G. R., He, K. B., Huo, H., Kannari, A., Klimont, Z., Park, I. S., Reddy, S., Fu, J. S., Chen, D., Duan, L., Lei, Y., Wang, L. T., and Yao, Z. L.: Asian emissions in 2006 for the NASA INTEX-B mission, Atmos. Chem. Phys., 9, 5131-5153, doi:10.5194/acp-9-5131-2009, 2009.

Zhou, Y., Brunner, D., Boersma, K. F., Dirksen, R., and Wang, P.: An improved tropospheric $\mathrm{NO}_{2}$ retrieval for OMI observations in the vicinity of mountainous terrain, Atmos. Meas. Tech., 2, 401-416, doi:10.5194/amt-2-401-2009, 2009. 